\title{
INDUSTRIAL POLICY AND COMPETITION ENFORCEMENT: IS THERE, COULD THERE AND SHOULD THERE BE A NEXUS?
}

\author{
Nicolas PETIT ${ }^{*}$ and Norman NEYRINCK ${ }^{* *}$
}

\section{Introduction}

As its title suggests, this paper muses on whether there can be, there is, and there should exist a nexus between European Union ("EU") competition law and industrial policy. A wellknown, long lasting grievance in the history of EU competition law is indeed that the European Commission ("the Commission") has allegedly enforced the competition rules dogmatically, and turned a blind eye on industrial policy considerations. ${ }^{1}$

Lately, however, this policy debate has revived. With the current economic debacle in the Western world, decades of free-market economic policies - including competition policies inherited from the so-called "Washington consensus" are called into question. In contrast, thriving economic models like Brazil, China, or India where the State interferes with the market at the expense of free competition, are increasingly looked by the "old world" as a possible source of inspiration. ${ }^{2}$

In parallel to this, the legal debate over the goals of EU competition law has never been so intense. The silence of the Treaties and the murky case-law of the EU courts on this issue have prompted scholars to invest countless efforts in eliciting those goals. Researches over the mindset of the antitrust lawmakers, the historical context surrounding the adoption of

\footnotetext{
* Professor, University of Liège (ULg), Belgium. Director of the Global Competition Law Centre (GCLC) College of Europe. Director of the Brussels School of Competition (BSC). Nicolas.petit@ulg.ac.be.

${ }^{* *}$ Assistant, University of Liège (ULg), Belgium, Lawyer.

${ }^{1}$ See Interview of F. HOLLANDE, "French presidential election: Exclusive interview with François Hollande and Nicolas Sarkozy", Concurrences, $\mathrm{N}^{\circ}$ 2-2012: "La politique de concurrence devrait poursuivre le même objectif que la politique industrielle, avec des moyens différents. Il faut cesser d'opposer de manière dogmatique ces deux politiques comme c'est parfois le cas aujourd'hui."

${ }^{2}$ Supporters of industrial policy have thus been increasingly numerous. And well-known sceptics have even joined the fray. In 2010, Mario MONTI, previously a remarked disbeliever of industrial policy during his tenure as Commissioner for competition, admitted that "The word [industrial policy] is no longer taboo". See M. MONTI, A New Strategy for the Single Market. At the service of Europe's economy and society, Report to the President of the European Commission José Manuel Barroso, 9 May 2010, p. 86 (available at: http://ec.europa.eu/bepa/pdf/monti_report final_10_05_2010_en.pdf). Similarly, Nobel Prize economist Paul KRUGMAN recanted previous academic positions, admitting that Industrial policy's not so bad".See P. KRUGMAN, "Industrial Policy's Not So Bad", Journal of Commerce, 8 May 1990 (also available at: http://www.pkarchive.org/economy/IndustrialPolicyNotBad.html).
} 
competition rules, etc. have mushroomed in EU competition journals. ${ }^{3}$ Interestingly, antitrust specialists are divided. Some believe that EU competition law pursues exclusively an economic objective, yet disagree on its exact content (consumer welfare, total welfare, efficiency, etc.). ${ }^{4}$ Others consider that the roots of EU competition law lie in ordo-liberal theory. ${ }^{5}$ A distinct group of authors argues again that "consumer choice" is the real purpose of the EU competition rules. ${ }^{6}$ And finally, others ascribe distinct, additional functions to competition law, including the pursuit of public policy objectives, such as environmental protection, cultural diversity, and possibly industrial policy. ${ }^{7}$

Those new policy and doctrinal developments justify devoting another paper to the question whether industrial policy considerations could and should inform EU competition enforcement. To address it, we follow a four steps methodology. We first solve definitional issues by describing the various possible meanings of "industrial policy" (I). Second, we follow a legalistic approach to review whether such considerations can, as a matter of positive law, play a role (II). Third, we turn to empirical analysis, to examine if there has been some industrial policy influence in the Commission's case-law (III). Fourth, we review consequentialist arguments to assess whether industrial policy considerations should play a stronger role in EU competition enforcement (IV).

\footnotetext{
${ }^{3}$ See S. SCHMITZ, “The European Commission's Decision in GE/Honeywell and the Question of the Goals of Antitrust Law”, University of Pennsylvania Journal of International Law, Issue 23 , 2002, p. 539; P. AKMAN, The Concept of Abuse in EU Competition Law: Law and Economic Approaches, Hart Publishing, 2012.

${ }^{4}$ See W. KERBER, "Should Competition Law Promote Efficiency? Some Reflections of an Economist on the Normative Foundations of Competition Law", in J. DREXL, L. IDOT and J. MONEGER (Eds.), Economic Theory and Competition Law, Cheltenham, Edward Elgar, 2008 (available at: http://papers.ssrn.com/soL3/papers.cfm?abstract id=1075265); K. HEYER, Welfare Standards and Merger Analysis:Why not the Best?, March 2006 (available at: http://www.justice.gov/atr/public/eag/221880.htm); K. CSERES, "The Controversies of the Consumer Welfare Standard", Competition Law Review, Vol. 3, No. 2, 2006, p. 121.

5 See L. PARRET, "Do we (still) know what we are protecting?", TILEC Discussion Paper, April 2009, p. 14 (available at: http://papers.ssrn.com/sol3/papers.cfm?abstract id=1379342); D. GERBER, "Constitutionalizing the Economy: German Neoliberalism, Competition Law and the "New" Europe", The American Journal of Comparative Law, Vol. 42, 1994, p. 25.

${ }^{6}$ See P. NIHOUL, 'Freedom of choice': The Emergence of a powerful Concept in European Competition Law, 5 June 2012 (available at: http://papers.ssrn.com/); J. ROSCH, Can Consumer Choice Promote Trans-Atlantic Convergence of Competition Law and Policy?, Concurrences Conference on "Consumer Choice": An Emerging Standard for Competition Law, Brussels, Belgium June 8, 2012 (available at: http://www.ftc.gov/speeches/rosch/120608consumerchoice.pdf); N. AVERITT, R. LANDE and P. NIHOUL, "Consumer choice" is where we are all going - so let's go together", Concurrences, No 2-2011.

${ }^{7}$ See C. TOWNLEY, Article 81 EC and Public Policy, Hart Publishing, 2009, 363 p.; B. VAN ROMPUY, Economic Efficiency: The Sole Concern of Modern Antitrust Policy, Wolters Kluwer, 2012, 498 p.; M. STUCKE, "Reconsidering Antitrust's Goals", Boston College Law Review, Vol. 53 (2012), p. 551; M. STUCKE, "Reconsidering Competition”, Mississippi Law Journal, Vol. 81 (2011), p. 107.
} 


\section{Definitional Issues}

The copious literature on industrial policy does not provide a cohesive, unified definition of the concept. ${ }^{8}$ Perhaps an acceptable baseline is thus to consider that "industrial policy embraces all acts and policies of the State in relation to industry". ${ }^{9}$ Beyond this, and on pain of oversimplifying, economic scholars generally distinguish two main types of industrial policies. We review them in turn.

\section{Targeted Industrial Policies}

A first type of industrial policies are the "targeted industrial policies". Those policies have received a whole range of labels in the literature, including controversial ones, such as "picking winners, saving losers", "colbertist" or "protectionist" policies. ${ }^{10}$

The common thread to all targeted industrial policies - and possibly the reason for the controversy that surrounds them - is that they seek to assist specific firms or sectors, chosen discretionarily on the basis of lose undefined criterions (e.g., labour protection, regional development, defence interests, international trade strategy, etc.). ${ }^{11}$ Often, thus, "targeted industrial policies" are perceived as arbitrary political interventions.

Targeted industrial policies are polymorphous. They resort to a wide array of measures that include trade barriers (tariffs, quotas, etc.), tax cuts, protective regulations, license requirements, limitations on public procurement opportunities, discriminatory standard setting, etc. ${ }^{12}$ Interestingly, two popular instruments of targeted industrial policies are State subsidies and government-sponsored M\&A.

Moreover, targeted industrial policies can be either reactive or proactive. Those policies are reactive when the State takes measures ex post to protect specific firms or sectors from

\footnotetext{
${ }^{8}$ For a review of the definitions that have been given through time to the notion of industrial policy, see L. WHITE, "Antitrust Policy and Industrial Policy: A View from the U.S.", NYU Law and Economics Research Paper No. 08-05, pp. 3 and 4 (available at: http://papers.ssrn.com/sol3/papers.cfm?abstract id=1091244).

${ }^{9}$ See A. EL AGRAA and B. BAYLISS "Competition and Industrial Policy with an emphasis on competition policy" in A. EL AGRAA (Ed.), The Economics of the European Community, Chapter 7, p.137; W. SAUTER, Competition Law and Industrial Policy in the EU, Oxford University Press, 1998, p.59 and the references at footnote 6.

${ }^{10}$ They are also referred to as "Mercantilist" policies, "Gaullist" policies, etc.

${ }^{11}$ See R. DRISCOLL and J. BEHRMAN, "Introduction”, in R. DRISCOLL and J. BEHRMAN (Eds.), National Industrial Policies, Cambridge, Oelgeschlager, Gunn and Hain, 1984, p. 5.

${ }^{12}$ Some good examples are provided in S. SINGHAM, Freeing the Global Market: How to Boost the Economy by Curbing Regulatory Distortions, October 2012 (available at http://www.cfr.org/economics/freeing-globalmarket/p29123).
} 
competitive hardship. Typically, a State awards rescue subsidies to ailing domestic firms harmed by cutthroat competition on international markets. Or a State acts as the knight in shining armor and takes the threatened domestic firms over (to undermine, possibly, risks of acquisition by a foreign operator). ${ }^{13}$ Or States may impose capital adequacy requirements for certain types of acquisitions.

Targeted industrial policies can also be pro-active, when governments take ex ante policy initiatives to create domestic "industrial champions". ${ }^{14}$ Examples of such policies include national efforts to grow domestic IT champions in the 1980s, with a view to defeat IBM's supremacy in computer markets. ${ }^{15}$

While in the past, targeted industrial policies generally tried to assist one specific firm in an industry (generally a flagship company), they are now increasingly applied at sector-wide level, for instance, to promote the emergence of "business clusters" on domestic territory. ${ }^{16}$ In spite of their apparent neutrality, those later policies are nevertheless "targeted" at specific firms. They indeed confer advantages to some market players and not to others (they do not benefit to firms who do not participate to the cluster). ${ }^{17}$ Hence, they may equally pervert the competitive process.

\section{Competitiveness Policies}

\footnotetext{
${ }^{13}$ For instance, with "golden shares". More generally, examples of such actions may be found in contemporary history, such as the failed attempts of Italian authorities to promote the union of two national banks (Antonveneta and Banca Popolare Italiana) against a Dutch offer (ABN Amro) or the similar, unsuccessful move for a union between two Spanish energy companies (Endesa and Gas Natural) against the takeover of a German competitor (E.On). See E. ZAERA CUADRADO, "Italian cross-border banking mergers: A case for Article 21 of the Merger Regulation?", Competition Policy Newsletter, 2005/3, pp. 95 and ff.; J. GALLOWAY, "The Pursuit of National Champions: The Intersection of Competition Law and Industrial Policy", European Competition Law Review, 2007 (available at: http://papers.ssrn.com/sol3/papers.cfm?abstract_id=1767865).

${ }^{14}$ This can happen directly if the firms are State-owned, or indirectly through political influence. In this variant, the State will encourage domestic companies to merge. The GDF-Suez merger is a textbook example of government support to the creation of a giant industrial champion. See L'express, "La fusion Suez-GDF en discussion à l'Elysée", 5 July 2007 (available at : http://www.lexpress.fr/actualite/politique/la-fusion-suez-gdfen-discussion-a-l-elysee 465356.html).

${ }^{15}$ In the UK's International Computers Limited (ICL), in France's Compagnie Internationale pour l'Informatique (CII), and in Italy's Olivetti. See, on this, G. OWEN, "Industrial Policy in Europe since the Second World War: What Has Been Learnt?", ECIPE Occasional Paper $N^{\circ} 1 / 2012$, pp. 5 and ff. (available at: http://www.ecipe.org/media/publication_pdfs/OCC12012-revised.pdf).

16 Examples of such policies include California's support to the US Silicon Valley, the Digital Media City in Seoul, etc. See M. KIM, "Planning for the next ICT cluster? Seoul's Digital Media City project", Technology and Society, 2002, p. 347.

${ }^{17}$ Interestingly, the more firm-selective the policy, the more anticompetitive.
} 
The second family of industrial policy are the so-called "competitiveness policies". In policy circles, they are viewed as policies that seek to ensure a positive balance of payments, i.e. that firms of a nation are collectively able to earn foreign exchange through exports by competing with firms from other nations globally. In other words, they are a pro-active trade instrument. ${ }^{18}$ They differ from the previous category in that they are not firm-specific. Economists call them "horizontal" policies to denote that they apply to all firms of the economy. $^{19}$

In general, competitiveness policies seek to correct "market failures" across industries, such as public goods, negative externalities, transaction costs, principal-agent problems, information asymmetries, coordination issues, etc. ${ }^{20}$ Competitiveness strategies can take many forms, from the granting of subsidies (e.g., to promote investments in infrastructures, educational programmes, $R \& D$ activities, etc.), to the adoption of specific regulatory frameworks (on SMEs, technology transfer, public procurement, technical standards, etc.).

At this stage, it is perhaps worth recalling that significant market power ("SMP") is a wellknown form of market failure. Accordingly, it is justified to classify policies that combat SMP, and in particular competition policies, as part of "competitiveness policies". ${ }^{21}$ At least this is the Commission's view. But competition policy is not the sole possible remedy for the elimination of significant market power. Alternative approaches include market-opening reforms (with sector-specific regulation), the subsidization of new entrants, etc.

And to make things even more complicated, competitiveness strategies and competition policy do not necessarily fare well. To understand this, one shall look a little further into what competitiveness means, from the firm's viewpoint. Firm competitiveness has two

\footnotetext{
${ }^{18}$ See S. CHAUDHURY and S. RAY, "The Competitiveness Conundrum. Litterature Review and Reflections", Economic and Political Weekly, Vol. 32, No. 48, 1997, pp. M83

${ }^{19}$ In the latter case, those sectors are selected under objective, predetermined criterions.

${ }^{20}$ This view is widely supported in the literature. See J.-L. GAFFARD, Why and How Revisiting Industrial Policy?, Frankreich ein Vorbild für Deutschland, Allemagne un exemple pour la France, Berlin, 19-20 June 2008 (available at: http://spire.sciences-po.fr/hdl:/2441/9945); F. MARTY, Politique de concurrence et politique industrielle européennes. La mise en cuvre du droit de la concurrence par la Commission revient-elle à une «antipolitique » industrielle ou traduit-elle une politique industrielle?, Colloque annuel du CEDE, Quelle politique européenne en matière de secteurs "stratégiques" ?, Paris, 28 January 2010 (available at: http://hp.gredeg.cnrs.fr/marty/ESSEC-MARTY_politique-industrielle.PDF).

${ }^{21}$ For a discussion of the goals ascribed to industrial policy and their compatibility with competition law: see S. EVENETT, Does the return of industrial policy pose a threat to competition law?, Mimeo, October 2006, pp. 4 and ff. (available at: http://www.ifri.org/files/Economie/Evenett.pdf). As will be seen below, the 2011 European Competitiveness Report dedicates one chapter on the importance of the alliance between competition and competitiveness.
} 
components. The first is price-competitiveness. It means that government should ensure that national firms are cost-efficient, or, in the language of economics, that they should achieve productive efficiency. This fares well with competition law, which is a good instrument to push firms towards efficient productive practices. The second component is non-price competitiveness. In a recent paper, Pascal LAMY, with his own words, defined non-price competitiveness as:

"those characteristics that cause a product to stand out positively among its competitors, regardless of price. In particular, it comprises know-how, quality and innovation, which allow a company to sell the same products as its competitors but at twice the price". ${ }^{22}$

Non-price competitiveness means, in other words, that government should make sure that firms enjoy some level of market power so as to increase prices above the competitive level. This is not entirely consistent with the policy outcome that antitrust rules seek to attain, at least if competition law follows a "consumer welfare" standard. Non-price competitiveness may, in contrast, be acceptable under competition regimes that apply distinct welfare standards, such as total (or producer) welfare.

\section{Synthesis}

In our view, two main features determine whether a specific public initiative falls into one or the other type of industrial policies. Those features are the scope and the timing of the measure. The more transversal and ex ante (i.e. proactive) the measure, the more it can be deemed a competitiveness measure. Conversely, the more individual and ex post (i.e. in reaction of a specific market event) the measure, the more it relates to "picking winners; saving losers" policies.

\footnotetext{
22 See P. LAMY, The Future of Europe in the New Global Economy, Notre Europe, February 2012 available at http://www.notre-europe.eu/media/P.Lamy_EuropeGlobalEconomy_NE_Feb2012_01.pdf
} 


\section{Figure 1: Cartesian Coordinate System of Industrial Policies}

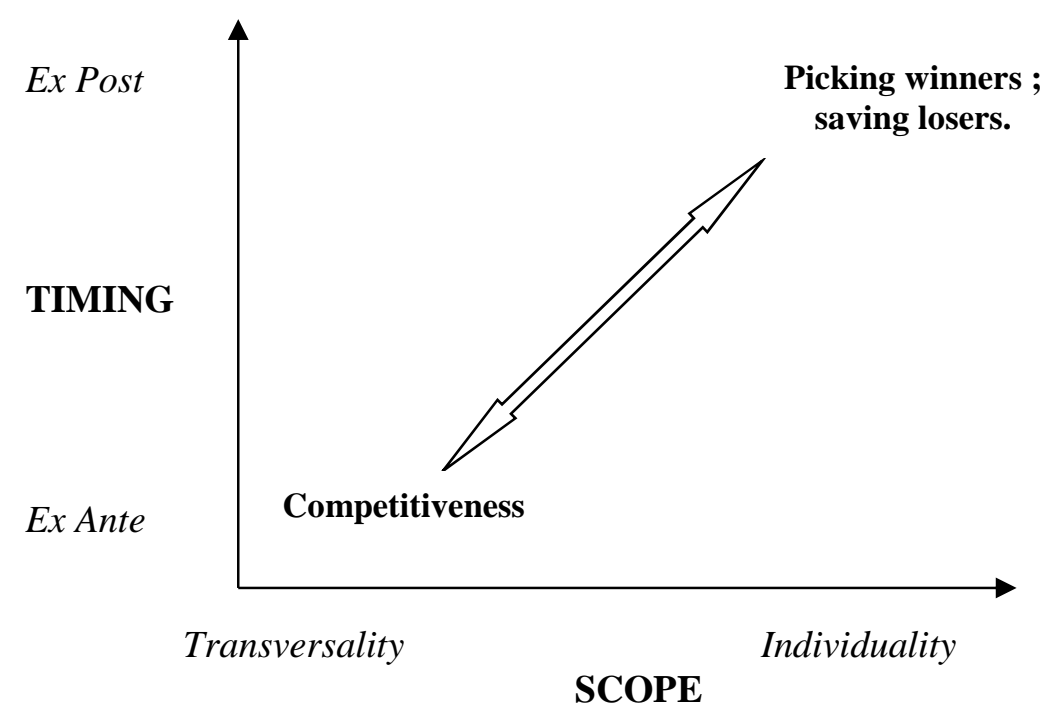

The boundary between "competitiveness policies" and "targeted industrial policies" is not always watertight. Accordingly, some industrial policy initiatives are difficult to classify. For instance, measures that create, promote and support business clusters may belong to either category, depending on their intrinsic features. Admittedly, such measures are adopted ex ante. They should thus fall within the "competitiveness policies" box. But the scope of business clusters varies significantly. Some business clusters are built around a broad research theme. Policies that support such business clusters accordingly benefit to many firms, active in distinct markets and/or sectors. Those policies thus come close to "competitiveness policies".

On the other hand, business clusters may involve a narrower set of firms active in a particular market and/or sector. Policy measures that assist such business clusters are closer to "targeted industrial policy" initiatives. And this is so regardless of their official designation (such measures are often said to be part of "competitiveness" agendas).

The bottom-line is that a case-by-case approach is warranted when it comes to classifying industrial policy programmes.

\section{Positivist (or Legalistic) Analysis}

Now that we have a better understanding of the notion of industrial policy, time is ripe to review if such considerations can play some role in EU competition law. In other words, is there an authoritative legal basis - textual or judicial - for the acclimation of industrial policy 
arguments in competition enforcement? In the following section, we first review this question from a general perspective (1), and then through the specific lenses of antitrust law (2), merger control (3) and State aid (4).

\section{Competition and Industrial Policy in the EU Treaties}

The EU competition rules do not form a stand-alone statute. They belong to a larger "framework" Treaty, the Treaty on the Functioning of the European Union ("TFEU"). This Treaty lays down a variety of other policies, including an industrial policy at Article 173 TFEU, which embraces at least formally, the "competitiveness" variant of industrial policies. ${ }^{23}$ One may thus question whether those policies - in the remainder, we call them "external" policies - shall, or not, influence EU competition enforcement, and how cases of conflicts between those policies must be resolved. ${ }^{24}$

In recent years, studies over this issue have sprouted. The works of TOWNLEY, VAN ROMPUY and others identify four scenarios for the coordination of EU external policies (e.g. environment, employment, culture, etc.) with competition policy. ${ }^{25}$ In a first scenario - they call it the "exclusion" scenario - the Treaty expressly allows external policy values to override, and exclude competition policy. For instance, Article 346(1) TFEU states that EU competition law does not preclude Member States to "take measures for the protection of the essential interests of their security".

In a second, hypothetical scenario - they call it the "compromise" scenario - competition policy would prescribe for a "balancing process", whereby violations of competition law could be balanced, and exonerated, against other, explicit policy criteria, listed in dedicated "balancing clauses". Those authors find no example of any such balancing process in relation to competition law. They however use the example of restrictions to the free movement of goods under Article 34 TFEU, which can be balanced against explicit public policy criteria, pursuant to Article 36 TFEU.

In a third scenario - which also involves some sense of compromise - the Treaty introduces a so-called "cross-sectional" or "policy-linking" clause, which requests competition

\footnotetext{
${ }^{23}$ Article 173 TFEU, which is the legal basis of the EU industrial policy, states that: "The Union and the Member States shall ensure that the conditions necessary for the competitiveness of the Union's industry exist".

${ }^{24}$ See B. VAN ROMPUY, Economic Efficiency: The Sole Concern of Modern Antitrust Policy, op. cit., p227.

${ }^{25}$ Ibidem. See also, C. TOWNLEY Article 81 EC and Public Policy, op. cit., pp.52-53.
} 
enforcement to take account of other policies in both its "definition and implementation". ${ }^{26}$ Such cross-sectional clauses exist in relation to environmental policy, consumer protection, culture, etc.

Finally, in a fourth scenario, the Treaty stays silent. In such cases, the issue is left to case-law determination. And the Court has traditionally sought to ensure consistent interpretations across policies, and refused to read each policy in isolation. In CILFIT, it held that, as a matter of principle:

« Every provision of Community Law must be placed in its context and interpreted in the light of the provisions of Community Law as a whole, regard being had to the objectives thereof and to its state of evolution at the date on which the provision in question is to be applied $\gg{ }^{27}$

Against this background, one may question if any of those four mechanisms was selected in the Treaty to coordinate the EU industrial policy with the Treaty rules on competition. Interestingly, none of them was retained. Rather, in relation to industrial policy, the Treaty introduced in 1992 a general reverse "exclusion" clause. Pursuant to Article 173(3) TFEU, industrial policy "shall not provide a basis for the introduction by the Union of any measure which could lead to a distortion of competition". The legal value of this provision is, however, difficult to discern. On the one hand, Article 173(3) seems to primarily target proposed EU legislative action, and to leave aside competition enforcement. How indeed can the Union introduce a distortion of competition when it enforces the competition rules?

At the other extreme, it may apply to all "Union" measures, including the Commission's decisional intervention against firm's conduct under the competition rules. In this context, Article 173(3) TFEU could prevent the Commission from exempting otherwise anticompetitive conduct on grounds of industrial policy. ${ }^{28}$

Given the uncertainty over the value of the general exclusion clause in relation to competition enforcement, it is apposite to turn to the case-law and the EU secondary legislation to

\footnotetext{
${ }^{26}$ See C. TOWNLEY, Article 81 EC and Public Policy, op. cit., p.53.

${ }^{27}$ See CJEU, 6 October 1982, Srl CILFIT and Lanificio di Gavardo SpA v Ministry of Health, 283/81, ECR, 1982, p. 3415 para. 20.

${ }^{28}$ See contra, C. TOWNLEY who considers that it is "an attempt to rule out the use of industrial policy in the Article 81(3) balancing exercise”. C. TOWNLEY, Article 81 EC and Public Policy, op. cit.,, p.160.
} 
scrutinize whether they bring more light on the relevance of industrial policy in EU competition law.

\section{Article 101 and 102 TFEU}

In this section, we seek to ascertain whether under the case-law and EU secondary legislation, pro-competitive agreements or unilateral conduct of a dominant firm can be forbidden out of industrial policy considerations (industrial policy as a theory of harm) (2.1); and (ii) anticompetitive agreements and abuses can be salvaged out of industrial policy defenses (industrial policy as a justification) (2.2).

\subsection{Industrial Policy as a Theory of Harm}

Article 101 TFEU cannot be enforced against pro-competitive conduct out of adverse industrial policy concerns (for instance, forbidding a joint R\&D agreement between non EU companies that compete with EU firms). Its wording makes it abundantly clear that the prohibition rule applies only to agreements that "have as their object or effect the prevention, restriction or distortion of competition".

The state of affairs is, however, not as straightforward in relation to Article 102 TFEU. On the one hand, the wording of Article 102 TFEU yields suspicion against dominant firms, which are often the archetype of industrial champions. Similarly, the case-law of the Courts subjects dominant undertakings to a "special responsibility" not to allow their conduct to impair genuine undistorted competition. ${ }^{29}$ This could be interpreted as a signal of defiance towards industrial champions.

On the other hand, however, the case-law has repeatedly stated that dominance is not, in and of itself, unlawful. ${ }^{30}$ More importantly, the EU Courts made crystal clear that a finding of unlawful abuse is conditional on proof that the impugned conduct hobbles competition. ${ }^{31}$ The Commission confirmed those principles in its Guidance Paper on its enforcement priorities in

\footnotetext{
${ }^{29}$ See GC, 30 September 2003, Atlantic Container Line and others v Commission, T-191/98, ECR, 2003, p. II03275 .

${ }^{30}$ See CJEU, 14 February 1978, United Brands Company and United Brands Continentaal BV $v$. Commission, Case 27/76, ECR 1978, p. 207, at 113; CJEU, 13 February 1979, Hoffmann-La Roche v. Commission, Case 85/76, ECR, 1979, p. 461 at 70.

${ }^{31}$ See CJEU, 13 February 1979, Hoffmann-La Roche v. Commission, Case 85/76, ECR, 1979, p. 461. In this case, the Court defined an abuse as behaviour "which, through recourse to methods different from those which condition normal competition in products or services on the basis of transactions of commercial operators, has the effect of hindering the maintenance of the degree of competition still existing in the market or the growth of that competition.",
} 
applying Article 82 EC (now Article 102 TFEU) to abusive exclusionary conduct by dominant undertakings (the "Guidance Paper"). ${ }^{32}$

Under the prohibition rules of Article 101 and 102 TFEU, ${ }^{33}$ the assessment is thus steeped into competition-related concerns, and only into such concerns.

\subsection{Industrial Policy as a Justification}

There is more merit to the contention that industrial policy considerations can provide ground for the absolution of otherwise anticompetitive conduct.

a). Article 101 TFEU

To start with Article 101 TFEU, its paragraph 3 enshrines a "balancing clause" which exonerates anticompetitive agreements that bring "improv[ements] in production or distribution of goods or to promoting technical or economic progress". This wording does not clearly declare public policy concerns, including industrial policy ones, admissible as exemption grounds. All the more so given that the Courts' case law consistently holds that exceptions are to be interpreted strictly. ${ }^{34}$

Remarkably, however, the case-law expanded the causes of justification under paragraph 3 to a raft of public policy concerns, unlisted in the Treaty. For instance, the EU judicature and the Commission demonstrably held that environmental benefits, ${ }^{35}$ the protection of

\footnotetext{
${ }^{32}$ See Guidance Paper on the Commission's enforcement priorities in applying Article 82 of the EC Treaty to abusive exclusionary conduct by dominant undertakings issued in December 2008, OJ, 2009, C 45/7. For a complete analysis, see N. PETIT, "From Formalism to Effects? The Commission's Communication on Enforcement Priorities in Applying Article 82 EC", World Competition, 32, 2002, p. 485.

${ }^{33}$ A distinct conclusion may, however, apply under national law. Under Article 3 of Regulation 1/2003, Member States are not precluded from applying on their territory stricter national competition laws on unilateral conduct, or apply stricter provisions if they predominantly pursue an objective different from Article 101 and 102 TFEU. It is unclear how this could form the basis for the introduction, in national law, of an industrial policy offense.

34 "According to settled case-law, having regard to the general principle of the prohibition of agreements restricting competition in Article 85(1) of the Treaty, provisions derogating therefrom in an exempting regulation must, by their nature, be strictly interpreted" See GC, Compagnie maritime belge SA v Commission of the European Communities, Case T-276/04, ECR, 2008 p. II-01277, para. 48; GC, Peugeot v Commission, Case T9/92 [1993] ECR II-493, paragraph 37

${ }^{35}$ See Commission Decision of 8 December 1983, IV/29.955 - Carbon Gas Technologie, 83/669/EEC, OJ, 31 December 1983, L 376/17; Commission Decision of 12 December 1990, IV/32.363 - KSB/Goulds/Lowara/ITT, 91/38/EEC, OJ, 25 January 1991, L 19/25 at para. 27; Commission Decision of 14 January 1992, IV/33.100 Assurpol, 92/96/EEC, OJ, 14 February 1992, L 37/16 at para 38; Commission Decision of 24 January 1999, (IV.F.1/36.718. - CECED), 2000/475/EC, OJ 26 July 2000, L187/47 at paras 51 and 57; Commission Decision of 17 September 2001, COMP/34493 - DSD, 2001/837/EC, OJ, 4 December 2001, L319/1; Commission Decision of 16 October 2003, COMP D3/35470 — ARA and COMP D3/35473 — ARGEV, ARO, 2004/208/EC, OJ, 12 March 2004, L 75/59.
} 
employment, ${ }^{36}$ cultural diversity and media pluralism, ${ }^{37}$ regional development, ${ }^{38}$ professional ethics, ${ }^{39}$ constituted legitimate factors to be taken into account when reviewing an agreement under Article 101(3) TFUE.

The exact substantive scope of this exception, and in particular its extension to industrial policy considerations is, however, unclear. On the one hand, the Court's case-law arguably views Article 101(3) TFEU as open-ended, possibly encompassing industrial policy concerns. ${ }^{40}$ In Métropole Télévision, the General Court held that "the Commission is entitled to base itself on considerations connected with the pursuit of the public interest in order to grant exemptions under Article 81(3) [now Article 101(3) TFEU]". ${ }^{41}$ The Court case-law rendered after the introduction of Article 173(3) TFEU in 1992 further confirmed this. In the Matra judgment of 1994, the Court held that industrial policy (i.e. an optimization of the manufacturing process) could outweigh an unlawful restriction of competition. ${ }^{42}$ This ruling suggests that the Court finds the reverse "exclusion" clause irrelevant, or simply inapplicable to Commission's decisions under the competition rules. ${ }^{43}$ This stream of case-law has been abundantly criticized, and authors have advanced many clever arguments to call its relevance into question. ${ }^{44}$

\footnotetext{
${ }^{36}$ See CJEU, 11 July 1985, Remia BV vs. Commission, C-42/84, ECR, 1985, p. 2545 at para 42; CJEU, 29 October 1980, Van Landewyck vs. Commission, Joined cases C-209/78 to 215/78 and 218/78, ECR, 1980, p. 3125 at para 182; Commission Decision of 4 July 1984, IV/30.810 - Synthetic Fibres, 84/380/EEC, OJ, 2 August 1984, L207/17 atpara 37.

${ }^{37}$ See Commission Decision of 25 November 1981, IV/428 - VBBB/VBVB, 82/123/EEC, OJ 25 February 1982, L54/36; CJEU 17 January 1984, VBVB and VBBB vs. Commission, Joined Cases 43 and 63/82ECR, 1984, p. 19; Commission Decision of 11 June 1993, IV/32.150 - EBU/Eurovision System, 93/403/EEC, OJ, 22 June 1993 L179/23, at para. 62. See, more generally, M. ARIÑO, "Competition Law and Pluralism in European Digital Broadcasting: Addressing the Gaps”, Communications \& Strategies, no. 54, 2nd quarter 2004, p. 97 at p.107.

${ }^{38}$ See Commission Decision of 23 December 1992, IV/33.814 - Ford Volkswagen, 93/49/EE, OJ, 28 January 1993, L20/14.

${ }^{39}$ See Commission Decision of 16 April 2002, Laurent Piau vs. FIFA, para 29. In this case, the Commission considered that the FIFA rules on the professional conduct for the occupation for players' agents worldwide "[t]hat can be justified by the general interest, are proportionate and compatible with competition law" (paras 6061). See, on this, E. LOOZEN, "Professional Ethics and Restraints of Competition", European Law Review, Vol.31, No.1, 2006, p.41.

${ }^{40}$ See C. TOWNLEY, Article 81 EC and Public Policy, op. cit., p.160.

${ }^{41}$ See GC, 18 September 2001, Métropole télévision (M6), T-112/99, ECR, 2001, II-2459, para 118.

${ }^{42}$ See GC, 15 July 1994, Matra Hachette SA v. Commission, T-17/93, ECR, 1994, II-595.

${ }^{43}$ Interestingly, the Court's case law provides only dim light on the type of acceptable industrial policy defenses, in particular on whether it covers only anticompetitive agreements that increase competitiveness or whether such defenses also apply to agreements that assist industrial winners and losers.

${ }^{44}$ Certain observers have sought to construe the occasional Commission and court references to non-competition benefits as obiter dicta. See L. GYSELEN, "The Substantive Legality Test under Article 81-3 EC Treaty Revisited in light of the Commission's Modernization Initiative”, in VON BOGDANDY, MAVROIDIS and MENY (Eds), European Integration and International Coordination, Studies in Transnational Economic Law in Honour of Claus-Dieter EHLERMANN, The Hague/London/New York, Kluwer Law International, 2002,536 p.
} 
On the other hand, the Commission's, and in particular its Directorate General for Competition ("DG COMP"), makes a conservative reading of Article 101(3) TFEU. ${ }^{45}$ Its Guidelines on Article 101(3) TFEU declare that public policy concerns are only admissible under Article 101(3) TFEU, provided that they (i) "are pursued by other Treaty provisions"; and (ii) "can be subsumed under the four conditions of Article 81(3) EC". ${ }^{46}$ In other words, the public policy concerns followed must "translat[e] into economic benefits" that satisfy the four conditions of Article 101(3) TFEU. ${ }^{47}$ With this, the Guidelines require an economic quantification of benefits which are not purely economic in nature. ${ }^{48}$ In practice, this may defuse the admissibility of industrial policy as a ground for exemption, simply because such concerns are not necessarily amenable to economic quantification and cannot therefore be "subsumed" under the four conditions of Article 101(3) TFEU in the manner envisaged by the Guidelines. ${ }^{49}$ For instance, it is unclear how an anticompetitive long-term supply agreement that fosters the security of energy supplies could be exempted, ${ }^{50}$ simply because its macroeconomic effects are uneasy to calculate under the Commission's orthodox micro-economic interpretation of paragraph $3 .^{51}$

In our view, the case-law of the Court should arguably take precedence over the Guidelines. This view is apparently shared by the Commission's Legal Service. In Brussels, rumour has it that the Legal Service has drafted an internal memorandum that shows that the Guidelines are illegal, as contradictory to the Court's case-law.

See contra, C. TOWNLEY, Article 81 EC and Public Policy, op. cit., p.66. Similarly, it has been argued that most of those non-competition concerns could be reconciled with the Guidelines approach, in that they contained an efficiency component. Finally, others have explained that such non-competition concerns were, by their very nature ancillary, and could thus potentially be taken into account within the Article 81(1) assessment under the ancillary restraints doctrine. See E. LOOZEN, "Professional Ethics and Restraints of Competition", op. cit.

${ }^{45}$ This view is also shared by G. MONTI, who believes that in the Commission's case-law, industrial policy arguments have been an ancillary motive for the granting of exemptions, and that in most cases, efficiencies could be demonstrated. See G. MONTI, EC Competition Law - Law in Context, Cambridge University Press, 2007, p.96.

${ }_{46}^{4}$ See para 40 of the Guidelines on Article 81(3).

47 See L. KJOLBYE, "The New Commission Guidelines on the Application of Article 81(3): An Economic Approach to Article 81", ECLR, 25(9), 2004, p. 570..

${ }^{48}$ See C. TOWNLEY, Article 81 EC and Public Policy, op. cit., p. 164.

${ }^{49}$ The rationale for this interpretation is to ensure that, with decentralisation, national competition authorities and courts will not exempt otherwise anticompetitive conduct on the basis of public policy goals. See L. KJOLBYE, "The New Commission Guidelines on the Application of Article 81(3): An Economic Approach to Article 81", op. cit., p. 570 ..

${ }^{50}$ For example, an agreement to build new generation capacity (a nuclear plant); an agreement to build a new pipeline for the transport of gas; a 25-year supply agreement between a gas producer and a gas distributor.

51 Which requires demonstration of "objective economic efficiencies" (e.g., synergies, economies of scale, of scope, etc.). 
Of course, the analysis must meet the so-called "practitioner's" objection, i.e. that even though it is a good thing for businesses to enjoy additional causes of justifications, any such industrial policy defense will be difficult to prove on the facts. And further objections may come from enforcer, who could legitimately fear that companies will avail themselves extensively of such industrial policy defences, at the expense of competition.

We believe that it is possible, however, to calibrate a clear, workable, and circumscribed industrial policy defense in EU competition law. First, because the EU's industrial policy is a competitiveness policy, then the defense should be a "competiveness" defense, rather than an elusive "industrial policy defense" based on unclear policy arguments, but conditioned on proof of verifiable competitiveness benefits. Second, the scope of admissible benefits is twofold. First, there can be price competitiveness benefits, in the form of gains in productive efficiency. Those are well known clients of competition enforcement, and competition authorities should have no problems to review and accept them. Second, there can be price competitiveness benefits. On this, competition authorities may have more qualms, given the second condition of Article 101(3) TFEU. But if the benefits accrued by the producer can be tied in to future investments, a relaxation could be necessary. At any rate, we believe that the problem of integrating competitiveness justifications within Article 101(3) TFEU are less acute when it comes to industrial policy justifications, because such defenses are generally economic in nature.

Overall, our interpretation is that otherwise anticompetitive agreements can thus be redeemed out of public policy considerations. ${ }^{52}$ Importantly, the fact that such agreements must pass the other three drastic conditions of Article 101(3) TFEU brings a safeguard against risks of socalled type II errors (false acquittals).

\section{b). Article 102 TFEU}

\footnotetext{
${ }^{52}$ Also referred to as "general interest" considerations. See, on this, C. TOWNLEY, Article 81 EC and Public Policy, op. cit.; A. KOMNINOS, "Non-Competition Concerns Resolution of Conflits in the Integrated Article 81 EC", EUI Paper, 2004, 12 p. (available at: http://www.eui.eu/RSCAS/Research/Competition/2004/200409compet-Komninos.pdf); G. MONTI, “Article 81 EC and Public Policy”, 30, 2002, Common Market Law Review, pp. 1057-1099; H. SCHWEITZER, "Competition Law and Public Policy: Reconsidering an Uneasy Relationship. The Example of Art. 81", in EUI Working Papers Law 2007/30, Italy (available at: http://cadmus.eui.eu/handle/1814/7623); J. BOURGEOIS, and J. BOCKEN, "Guidelines on the Application of Article 81(3) of the EC Treaty or How to Restrict a Restriction, Legal Issues of Economic Integration - Legal Issues of European Integration, Vol. 32, No. 2, 2005, pp. 111; P. LUGARD and L. HANCHER, "Honey, I Shrunk the Article! A Critical Assessment of the Commission's Notice on Article 81(3) of the EC Treaty", European Competition Law Review, Vol. 7, 2004, p. 413.
} 
Unlike in Article 101 TFEU, there is no balancing clause in Article 102 TFEU. In turn, the issue of an exemption of abuses on industrial policy grounds may be dismissed from the outset as moot.

That said, with its Guidance paper on Article 102 TFEU, the Commission introduced two balancing clauses through the backdoor. Those balancing clauses entitle a dominant firm to eschew a finding of infringement by (i) arguing that its otherwise anticompetitive conduct is "objectively necessary"; or (ii) claiming that the impugned conduct yields "substantial efficiencies which outweigh any anticompetitive effects on consumers". ${ }^{53}$ This is consistent with the Court's case-law. In a string of past judgments, the Court ruled that otherwise abusive conduct could be objectively necessary to achieve non-competition purposes, such as for instance health or safety protection. ${ }^{54}$

And in its 2011 Grand Chamber ruling in Post Danmark, the Court ratified ex post the validity of the second justification. It held that dominant firms can escape a finding of abuse, if proof is brought that:

"the efficiency gains likely to result from the conduct under consideration counteract any likely negative effects on competition and consumer welfare in the affected markets, that those gains have been, or are likely to be, brought about as a result of that conduct, that such conduct is necessary for the achievement of those gains in efficiency and that it does not eliminate effective competition, by removing all or most existing sources of actual or potential competition". 55

Those judgments are a far cry from introducing an Article 102(3) TFEU exemption which would absolve abusive conduct, possibly on industrial policy grounds. The analysis takes place within Article 102 TFEU, and thus bears more resemblance to the "rule of reason" methodology applied in US antitrust law.

It is, however, not entirely unconceivable, on the basis of this case-law, to envision some space for industrial policy defenses within Article 102 TFEU, all the more so in respect of competitiveness policies. After all, the Court has been wary to ensure consistency across the various domains of EU competition law (this can be referred to as "tranversal consistency").

\footnotetext{
${ }^{53}$ See para. 27: "In the enforcement of Article 82, the Commission also intends to examine claims put forward by a dominant undertaking that its conduct is justified. A dominant undertaking may do so either by demonstrating that its conduct is objectively necessary or by demonstrating that its conduct produces substantial efficiencies which outweigh any anticompetitive effects on consumers. In this context, the Commission will assess whether the conduct in question is indispensable and proportionate to the goal allegedly pursued by the dominant undertaking".

${ }^{54}$ See the cases quoted at footnote 20 of the Guidance paper.

${ }^{55}$ See CJEU, 27 March 2012, Post Danmark A/S v Konkurrencerådet, Case C-209/10, not yet reported, para. 42.
} 
In practice thus, if a balancing clause entitles industrial policy concerns to override restrictions of competition under Article 101 TFEU, then the Court should equally immunize restrictions of competition under Article 102 TFEU. The form of the conduct, i.e. coordinate v. unilateral conduct, is simply irrelevant.

Second, the Court has accepted in Meca Medina and Wouters that public policy balancing could take place within Article 101(1) TFEU, in a spirit reminiscent of the rule of reason. ${ }^{56}$ Again, on grounds of transversal consistency, if a rule of reason is to be applied within Article 102 TFEU as suggested by Post Danmark, then the assessment should be congruent with the principles that govern the Article 101(1) TFEU rule of reason, and accordingly should include a possible exoneration on public policy considerations.

\section{Merger Control}

In this section, we review the same questions, this time in relation to merger control. Put simply, under the EU Merger Regulation ("EUMR"), ${ }^{57}$ can the Commission forbid a procompetitive merger (2.1), or salvage an anticompetitive one (2.2), out of industrial policy reasons?

\subsection{Industrial Policy as a Theory of Harm}

The question whether the Commission can veto a merger on industrial policy grounds is mainly about targeted industrial policy and, more specifically, the protection of local EU firms against foreign operators. In this regard, the issue is whether EUMR enforcement can be selectively targeted against foreign operators, either to block their proposed mergers or to submit them to conditions, at the benefit of European players. To take a few hypothetical examples, could the Commission block a merger between non EU firms on the ground that the transaction creates a super-efficient industrial giant likely to outcompete European rivals? Or could it attempt to forbid the takeover of a European firm by a foreign operator, simply because it is deemed strategically important to keep those assets in European hands.

\footnotetext{
${ }^{56}$ CJEU, 19 February 2002, J.C.J. Wouters, J.W. Savelbergh, Price Waterhouse Belastingadviseurs BV v. Algemene Raad van de Nederlandse Orde van Advocaten, Case C-309/99, ECR, 2002, I-1577, para. 108 . CJEU, 19 July 2006, Meca Medina and Majcen v Commission, Case C-519/04 P, ECR, 2006, I-6991, para. 45.

${ }^{57}$ See Council Regulation (EC) No. 139/2004 of 20 January on the Control of Concentrations Between Undertakings, OJ, 29 Januray 2004, L24/1.
} 
A cautious reading of the text of the EUMR suggests the absence of a legal basis for any such industrial policy offense. The concept of "industrial policy" is not even once mentioned in the text. Moreover, the core provision of the EUMR, i.e. the prohibition standard set at 2(3), only talks of a "significant impediment to effective competition". As if this was not sufficient, Article 2(2) further declares that mergers that do not significantly impede competition are presumably lawful.

Mergers can thus only be forbidden on competition grounds, and on no other consideration. And twice in 1973 and $1981,{ }^{58}$ the Council rejected proposals to insert a wider "public interest" prohibition standard in the Regulation.

\subsection{Industrial Policy as a Justification}

In the EUMR, there is no "balancing clause" that can exonerate anticompetitive mergers out of public policy - and a fortiori industrial policy - reasons. Surely, Article 2(1) expresses a favourable stance towards mergers that promote "technical and economic progress". Yet, it insists in turn on the absence of any "obstacle to competition".

Things have, however, slightly changed with the introduction of an "efficiency defense" in the Guidelines on horizontal mergers of 2004 (the "Guidelines"). Of course, the wording of the Guidelines makes clear that the efficiency defense is no Trojan horse for redeeming industrial policy arguments. ${ }^{59}$ Whilst the Guidelines consider that efficiencies "are capable of increasing the competitiveness of industry", 60 and that "the Commission performs an overall competitive appraisal of the merger. In making this appraisal, the Commission takes into account the factors mentioned in Article 2(1), including the development of technical and economic progress", from an operational standpoint, efficiencies only lead to clearance if they "counteract the effects on competition and in particular the potential harm to consumers". 61 In other words, the sole admissible efficiencies are pro-competitive effects that trump risks of significant impediment of effective competition in the first place. ${ }^{62}$ Again, the test appears

\footnotetext{
${ }^{58}$ See D. GERADIN and I. GIRGENSON, "Industrial Policy and European Merger Control - A Reassessment", TILEC Discussion Paper No. 2011-053, October 2011, p. 7 (available at: http://papers.ssrn.com/sol3/papers.cfm?abstract_id=1937586).

${ }^{59}$ On this issue, see L. ORTIZ BLANCO, Market Power in EU Antitrust Law, Hart Publishing, 2012p.76. [Ref.]

${ }^{60}$ See Guidelines on the assessment of horizontal mergers under the Council Regulation on the control of concentrations between undertakings, OJ, 5 February 2004, C 31/5, para. 76.

${ }^{61}$ Ibid.

${ }^{62}$ This is confirmed at para. 77: "as a consequence of the efficiencies that the merger brings about, there are no grounds for declaring the merger incompatible with the common market pursuant to Article 2(3) of the Merger Regulation. This will be the case when the Commission is in a position to conclude on the basis of sufficient evidence that the efficiencies generated by the merger are likely to enhance the ability and incentive of the
} 
only competition-related. And in practice, such "efficiency defenses" are very difficult to prove. $^{63}$

The same is true of the "failing firm defense" ${ }^{64}$ Concentrations authorised under this defense are not exonerated out of "saving losers" concerns. They are cleared if it can be proved that the anticipated harm to competition is not caused by the merger.

But given the striking resemblance between the wording of the efficiency defense and of Article 101(3) TFEU, the question arises whether the public policy defences recognized by the Court under Article 101(3) TFEU, including possible industrial policy defenses, could be transposed in EUMR enforcement. ${ }^{65}$ To be fair, there are solid theoretical arguments - besides the abovementioned principle of "transversal consistency" - in support that all Article 101(3) TFEU justifications should be transposed under the merger efficiency defense. ${ }^{66}$ After all, mergers are the ultimate form of agreements amongst companies. Moreover, Article 101(3) TFEU is already applied within EUMR proceedings. Full-function joint ventures that give rise to coordination, pursuant to Article 2(4) of the EUMR, can be exonerated on the basis of Article 101(3) TFEU.

Similarly to Article 101 and 102 TFEU, there might thus be space for an industrial policy defense under the EUMR.

\subsection{Member States?}

As seen above, the Commission is deprived of the power to ban a pro-competitive merger on industrial policy grounds (an industrial policy offense). Interestingly, the Member States seem to enjoy more leeway than the Commission in this context. Pursuant to Article 21(4) of the EUMR, the Member States can undermine mergers notified to the Commission out of public policy concerns. Article 21(4) entitles them to claim jurisdiction over certain EU-wide

merged entity to act pro-competitively for the benefit of consumers, thereby counteracting the adverse effects on competition which the merger might otherwise have".

${ }^{63}$ Efficiency gains were one of the central arguments in favor of the Euronext Deutsche Börse/NYSE Euronext merger, with alleged liquidity enhancement effects and less collateral requirements for security. The Commission rebuffed these allegations, with a radical stance: "In any case, any efficiencies would not be substantial enough to outweigh the harm to customers caused by the merger". See Commission Press Release, "Mergers: Commission blocks proposed merger between Deutsche Börse and NYSE Euronext", 1 February 2012, IP/12/94.

${ }^{64}$ See L. PERSSON, “The Failing Firm Defense", The Journal of Industrial Economics, Volume 53, Issue 2, 2005, p. 175; OECD, Failing Firm Defence, 1995, OCDE/GD(96)23.

${ }^{65}$ Or whether the Meca Medina and Wouters-inspired, rule of reason analysis could be applied.

${ }^{66}$ Beyond the point that there should be transversal consistency across the various areas of EU competition law. 
mergers, and take appropriate measures to protect "legitimate interests" others than those covered by the EUMR. That said, there is a large consensus, in the scholarship, that Article 21(4) has been applied very restrictively (to the exception, maybe, of the defense sector).

\section{State Aid Law}

On State aid, things are somewhat simpler. Unlike antitrust and merger control, the law on State aid more clearly accommodates industrial policy considerations. In particular, it seems to tolerate both subsidies and other aid measures granted in the context of "competitiveness" and "targeted" industrial policies, though with significant differences. We review those two aspects of State aid law in turn.

\subsection{State Aid Law and the Quasi Per Se Legality of "Competitiveness" Subsidies}

True competitiveness subsidies cannot be banned under State aid law. This is because the prohibition rule of Article 107 TFEU is wholly ineffective in so far as genuine competitiveness subsidies are concerned. Under Article 107 TFEU, only those State measures that are "selective" give rise to competition law concerns. As a result, a conventional competitiveness measure that applies transversally - one would say horizontally - to all firms cannot be deemed a State aid, and should thus not be forbidden.

Moreover, State aid law comprises a "balancing clause", which further corroborates that competitiveness subsidies benefit from a quasi per se legality regime under Article 107 TFUE. The wording of Articles 107(3)(a) and 107(3)(c) TFEU declares that aid may be held compatible with the internal market if needed "to promote the economic development of areas where the standard of living is abnormally low, or where there is serious underemployment", or "to facilitate the development of certain economic activities or of certain economic area". And interestingly, the Commission's General Block Exemption Regulation ("GBER”) considers that the elimination of "market failures" - i.e. the primary purpose of competitiveness policies - is the substantive lynchpin of Articles 107(3)(a) and 107(3)(c) TFEU: 
"Having regard to Articles [107](3)(a) and [107](3)(c) of the Treaty, (...) aid should be proportionate to the market failures or handicaps that have to be overcome in order to be in the Community interest." 67

To bring even more credence to this point, the concept of "market failure" is referred to fourteen times in the preamble of the GBER. And the remainder of the GBER is replete with examples of aid measures that can be exempted because of their ability to address market failures. For instance, aids for research, development and innovation schemes or aid for professional training and retraining are deemed appropriate to overcome risks of underfinancing arising from "negative externalities". 68 Similarly, aids for SMEs or to encourage female entrepreneurship are needed to address credit restrictions resulting from imperfect or asymmetric information (i.e. firms do not obtain funding despite having a valuable business model and growth prospects). ${ }^{69}$

In sum, the above suggests that competitiveness subsidies (and other aids) come close to a per se legality regime under EU competition law. In practice, Member States are free to introduce competitiveness policies through aid measures, without risking running afoul of Article 107 TFEU. $^{70}$

\subsection{State Aid Law and the Rule of Reason Approach to "Targeted Industrial" Aid}

Whilst State aid law exhibits sympathy for competitiveness policies, the same benevolence does not apply to targeted industrial aid granted with a view to "pick winners" or "save losers". Those measures are selective in nature. They thus constitute the very form of aid that the prohibition rule of Article 107 TFEU targets. In other words, the pursuit of targeted industrial policies through State aid constitutes an offense in modern EU competition law.

That said, State aid law is not hostile to such aids, in particular in their "saving losers" variant. For obvious political and social reasons, State support to ailing firms cannot be totally ruled out. In a set of Guidelines on "aid for rescuing and restructuring firms in difficulty", the

\footnotetext{
${ }^{67}$ See Commission Regulation No 800/2008 of 6 August 2008 declaring certain categories of aid compatible with the common market in application of Articles 87 and 88 of the Treaty (General block exemption Regulation), OJ, 9 August 2008, L 214/3 para. 35.

${ }^{68}$ Ibid., para. 57 and 62.

${ }^{69}$ See GBER, para. 56.

${ }^{70}$ This is made explicit in several documents. See for instance: State aid action plan - Less and better targeted state aid: a roadmap for state aid reform 2005-2009, COM/2005/0107 final.
} 
Commission thus introduced a "balancing clause" which entitles otherwise anticompetitive aid to benefit from an exemption.

Interestingly, the conditions under which an exemption may be granted attempt to transform the proposed "targeted industrial policy" measure into a "competitiveness" measure. ${ }^{71}$ This can be seen in two distinct respects. First, the ailing firm must present a restructuring plan to the Commission that is supposed to lead to a redress of its competitiveness.

Second, and more remarkably, the Commission insists on the adoption of "adequate compensatory measures in favor of competitors", 72 whose purpose is to mitigate the targeted nature of the proposed aid, and to reintroduce a degree of horizontality, in the spirit of "competitiveness policies". In plain language, the Commission's view is that all market players should receive something: the aided firm benefits from financial support, its rivals obtain compensation.

Compensatory measures are polymorphous. Structural measures consist in the divestiture of assets of the aided firm towards competitors, in particular where the aided firm occupies a large market position. ${ }^{73}$ For instance, in the Bankgesellschaft Berlin (BGB) $A G$ case $^{74}$ the restructuring plan was approved in exchange of heavy divestitures including the hiving-off of BGB's real estate services and real estate financing subsidiaries, and the divestment of Berliner Bank, one of BGB's retail brands. ${ }^{75}$

But compensatory measures may also be behavioral. In the MobilCom AG case, ${ }^{76}$ the Commission prohibited MobilCom AG from selling telephony contracts online for a period of

\footnotetext{
${ }^{71}$ See Communication from the Commission, Community guidelines on State aid for rescuing and restructuring firms in difficulty, OJ, 1 October 2004, 244/2.

${ }^{72}$ Ibid., para. 7 and 31.

${ }^{73}$ Ibid., para. 39: "These measures may comprise divestment of assets, reductions in capacity or market presence and reduction of entry barriers on the markets concerned".

74 See Commission Decision of 18 February 2004 on restructuring aid implemented by Germany for Bankgesellschaft Berlin AG, 2005/345/EC, OJ, 4 May 2005, L 116/1

${ }^{75}$ The diverse compensatory measure to reduce BGB's business volume were planned to reduce its balance sheet total from roughly $€ 189$ billion in 2001 to about $€ 124$ billion in 2006/2007. See E. GRAEPER and S. MOSER, "Enforcement of State aid control in the banking sector: Bankgesellschaft Berlin AG", Competition Policy Newsletter, Number 2, Summer 2004, pp. 94-96.

${ }^{76}$ See Commission Decision of 14 July 2004 on the State aid implemented by Germany for MobilCom AG, 2005/346/EG, OJ, 4 May 2005, L $116 / 55$.
} 
7 months. The Commission found that halting MobilCom AG's online marketing operations for a while would help competitors increase their foothold in online contracts. ${ }^{77}$

\section{Empirical Perspective}

We now turn to the question whether there has been an industrial policy agenda in EU competition enforcement. In other words, have industrial policy considerations actually informed the Commission's decisional practice under the competition rules? We deal with this issue by reviewing the three areas of EU competition enforcement where such considerations can play a role, namely antitrust law (1), merger control (2) and State aid (3). ${ }^{78}$

\section{Article 101 and 102 TFEU}

\subsection{Article $101 \mathrm{TFEU}$}

Most authors agree that, until 1992, the Commission occasionally accepted industrial policy arguments under the exemption rule of Article 101(3) TFEU. This policy had two dimensions: the Commission exempted crisis cartels on the one hand, and it exempted agreements purporting to strengthen European industry, vis-à-vis global competitors. ${ }^{79}$ Scholars remain, however, divided, over the real nature of this policy. For instance, G. MONTI argues that those agreements generated efficiencies at any rate, and that those efficiencies were the true basis for the exemption. In his own words: "industrial policy is not a sufficient condition for exempting an agreement". ${ }^{80}$ In contrast, C. TOWNLEY disagrees, and contends that industrial policy "is one of the most heavily used objectives in the Article 81(3) balance". ${ }^{81}$

Following the abolition of the notification procedure by Regulation 1/2003, exemption decisions have waned. ${ }^{82}$ The Commission has thus had fewer opportunities to pursue industrial policy choices. Surely, the Commission can still take exemption decisions under Article 101(3) TFEU. But it has shown a remarkable disinterest for such cases.

\footnotetext{
77 See S. CROME and A.SÖLTER, "Conditional decisions and EC State aid law: The MobilCom case", Competition Policy Newsletter, Number 3, Autumn 2004, pp. 55-57.

${ }^{78}$ Our analysis seeks to identify macro-decisional trends in the Commission's case-law. It thus discards occasional cases where industrial policy considerations may have occasionally have infiltrated the Commission's analysis.

${ }^{79}$ See G. MONTI, EC Competition Law - Law in Context, op. cit., p.94.

${ }^{80}$ Ibid., p.96.

${ }^{81}$ See C. TOWNLEY, Article 81 EC and Public Policy, op. cit. [___].

${ }^{82}$ It would be beyond the scope of this paper to conduct the assessment in national case-law. That said, since the Tele2 Polska case, it is doubtful that National Competition Authorities can still take exemption decisions under Article 101(3) TFEU.
} 
Most of the Commission's enforcement resources have in contrast been channeled towards cartel cases. And if, in this area again, industrial policy considerations could have permeated, to our best knowledge, no cartel cases have given rise to "crisis-exemption" defenses.

In reality, the sole areas where the Commission may have planted industrial policy considerations are the numerous sets of Guidelines adopted to clarify the application of Article 101 TFEU. Yet, those texts resort to abstract and vague wording. It is therefore complex to identify industrial policy choices in those documents. All the more so given that in substance, those texts endorse an orthodox economic approach for the assessment of agreements, agnostic to industrial policy concerns.

\section{Article 102 TFEU}

The enforcement track record under Article 102 TFEU is more substantial. We can then test, in turn, whether the Commission has followed targeted industrial policy goals (2.1.) and “competitiveness policy" objectives (2.2), in enforcing Article 102 TFEU.

\section{1. "Targeted industrial policy" under Article 102 TFEU?}

Dominant firms are the prototype of an industrial champion. With this in mind, there are two hypothesis in which Article 102 TFEU enforcement may have ventured into targeted industrial policy considerations. First, the Commission may have exhibited leniency towards dominant European champions, by reneging on enforcing Article 102 TFEU, or by closing cases lodged against them (for instance, on the basis of objective justifications or efficiencies). On the facts, however, the Commission's case-law yields no evidence of this, much to the contrary. Most Article 102 TFEU cases decided since 1 May 2004 (see Annex I) concern incumbent operators in network industries: Telefónica, Telekomunikacja Polska S.A, Distrigaz, ENI, RWE, GDF etc. Those operators well impersonate the notion of national champions. So if the Commission has been anything under Article 102 TFEU, it is being tough on dominant national champions.

Second, the Commission may have selectively, and aggressively, enforced Article 102 TFEU against global competitors of EU rivals. At first glance, the case-law could seem supportive of this hypothesis: many abuse of dominance cases since 1 May 2004 concern non-European firms, particularly US firms in the ICT industry: Coca-Cola, S\&P, IBM, Microsoft, Rambus, 
Intel, etc. But this is no proof of a hidden industrial policy agenda, whereby the Commission would seek to protect the European rivals of those dominant firms. Indeed, in almost all those markets, in particular in the ICT industry, the dominant firms found guilty of abuse by the Commission had no European competitors. How could the Commission possibly protect something that doesn't exist?

\section{2. “Competitiveness Policy" under Article 102 TFEU?}

To address this issue, one should first determine what the main components of the EU competitiveness policy are, and then scrutinize whether the Commission's Article 102 TFEU practice has made decisional forays into such areas.

As seen above, the legal basis of the EU's industrial policy can be found at Article 173 TFEU. But its substantive content is defined in a 2010 Communication entitled "An Integrated Industrial Policy for the Globalisation Era - Putting Competitiveness and Sustainability at Centre Stage". This policy has a gaggle of components: "smart regulation", "access to finance for businesses", "single market" ("approximation of law" and "European IP rights"), "counterfeiting and piracy", "competition policy", "energy transport and communication infrastructure", "stronger role for European standard setting", "industrial innovation policy", "education and training policies", "international trade regulation", "ensuring access to raw materials and commodities", "stimulate resource efficient investment throughout industry" and the removal of "structural overcapacities". 83

It would be beyond the scope of this report to run through this laundry list of items. And in relation to many of them, competition law seems in any case toothless (e.g., counterfeiting and piracy policies, education and training policy, smart regulation, etc.).

Looking at the list of cases adopted since 1 May 2004 (see Annex I), the sole obvious item of the EU competitiveness agenda that seems prevalent in Article 102 TFEU enforcement is the "energy, transport and communication infrastructure" item. On this, the Communication had this to say:

\footnotetext{
${ }^{83}$ See Communication from the Commission to the European Parliament, the Council, the European Economic and Social Committee and the Committee of the Regions, An Integrated Industrial Policy for the Globalisation Era. Putting Competitiveness and Sustainability at Centre Stage, $\operatorname{COM}(2010)$ 614, 33 p. (available at: http://ec.europa.eu/enterprise/policies/industrial-competitiveness/industrial-policy/files/communication_on industrial_policy_en.pdf).
} 
"In many Member States, increasing competition in the network industries remains a challenge. [...] Certain European network services are often provided at a relatively high price. European electricity prices are on average high by international standards. A stronger enforcement of competition rules in the sector is necessary to reduce competition distortions such as abuses of dominant position by market players". ${ }^{84}$

The Commission's underlying concern is that supra-competitive prices in network industries risk putting the EU's manufacturing industry at a significant disadvantage in the global markets. $^{85}$

It cannot be sure that DG COMP chose to steer its enforcement resources towards those sectors in a deliberate effort to assist the EU competitiveness policy, especially because those cases predated the 2010 Communication. But since 2010, DG COMP keeps scrutinizing network industries under Article 102 TFEU. In 2010, for instance, all four Article 102 TFEU cases adopted by the Commission concerned the energy sector. ${ }^{86}$ And more cases of this kind are currently in the Commission's decisional pipe-line. Hence, it is fair to say that at least in respect of this component, EU competition and industrial policies walk the same line.

\section{Merger Control}

In this section, we test whether, on the one hand, the EU merger enforcement practice has sought to achieve "targeted industrial policy" outcomes concerns (1.1), and on the other hand, whether it has sought to further the EU's competitiveness agenda (1.2).

\subsection{Targeted Industrial Policy under the EUMR?}

There are good intuitive reasons to test empirically whether the enforcement of the EU Merger Regulation ("EUMR") has espoused targeted industrial policy considerations. First, merger proceedings are less protracted, and more confidential, than standard antitrust proceedings under Articles 101 and 102 of the Treaty on the Functioning of the EU ("TFEU”). Thus, the Commission has possibly more leeway to play Lego with markets, hidden in the procedural shadow, and achieve targeted industrial policy results within short timeframes. Second, merger decisions are subject to light touch judicial scrutiny. In this field,

\footnotetext{
${ }^{84}$ Ibid., pp.10 and 11.

${ }^{85}$ Ibid.. at p. 11.

${ }^{86}$ See Commission Decision of 17 March 2010, Case COMP/39.386 - Long-term contracts France; Commission Decision of 14 April 2010, COMP/39351 - Svenska Kraftnät / Dansk Energi,; Commission Decision of 4 May 2010, COMP/39.317 - E.ON Gas; Commission Decision of 29 September 2010, COMP/39.315 - ENI, OJ, 23 December 2010, C 352/8.
} 
the General Court ("GC") indeed bestows a large margin of appreciation upon the Commission. ${ }^{87}$ Altogether, those aspects make merger control a potentially good candidate to industrial politicization.

From a methodological standpoint, there are again two possible ways to assess whether "picking winners, saving losers" arguments have played a role in merger control. A first possible way consists in determining whether the Commission banned procompetitive mergers that would threaten national and/or European champions. On this, however, the evidence is inconclusive. First, the rate of formal prohibitions is generally too low to provide a statistically significant figure. Second, 19 out of the 22 prohibition decisions adopted to date concern firms with "European" origins and with their main footprint in the EU. In contrast, only three of them seem to target firms with a extra-European origins, i.e. Gencor/Lonhro, MCI WorldCom/Sprint and GE/Honeywell. Third, most of the reported attempts to induce the Commission to block a merger on industrial policy grounds have apparently failed. The clearance decisions in Boeing/McDonnell Douglas, Arcelor/Mittal, Albertis/Autostrade, Alcan/Pechiney, despite intense lobbying campaigns against those mergers, bring a glaring confirmation of this. ${ }^{88}$

A second possible approach to determine if "picking winners, saving losers" considerations have informed merger enforcement lies in checking whether the Commission ever cleared anticompetitive mergers that meanwhile were deemed to create, promote or protect national/European champions. Here again, however, the evidence is mixed. The Commission may have occasionally cleared anticompetitive mergers, simply because they gave rise to industrial titans. G. MONTI cites as possible examples the Alcatel/Telettra, Mannesmann/Vallourec/Ilva, and Piaggio/Aprilia mergers. That said, the merger case-law also abounds with examples of forbidden transactions, despite Member States' vindication

\footnotetext{
${ }^{87}$ Moreover, merger decisions with remedies are rarely subject to annulment proceedings, simply because the parties, who have offered them, are presumed to be happy with them. On the light standard of judicial review in merger cases, see J. HERNÁNDEZ, Discretion and judicial review in merger control (some lessons learned from the risk management administrative procedures), Third Biennial conference of the Standing Group on Regulatory Governance of the ECPR and Regulatory Network, University College Dublin, June 17-19 2010 (available at: http://papers.ssrn.com/sol3/papers.cfm?abstract id=1625996); T. REEVES and N. DODOO, "Standards of Proof and Standards of Judicial Review in European Commission Merger Law", Fordham International Law Journal, 2005, p. 1034.

${ }^{88}$ See Libération, "Chirac blâme la fusion Boeing-McDonnell Douglas", 17 July 1997; Y DE KEDRELL, "Quand le capitalisme français renoue avec ses vieux démons", Le Figaro, 17 October 2007; L'expansion, "La fusion entre Abertis et Autostrade critiquée en Italie", 24 April 2006; B. ABESCAT, "Chirac, mauvais patron", L'Express, 20 February 2002.
} 
that they would lead to the creation of industrial champions. The Aérospatiale-Alenia/de Havilland, ${ }^{89}$ MSG/Media Services, ${ }^{90}$ Volvo/Scania, ${ }^{91}$ Schneider/Legrand, ${ }^{92}$ and Olympic/Aeagean Airlines decisions are good proof of this. ${ }^{93}$ In its latest prohibition decision in Deutsche Börse/NYSE Euronext, the Commission again vetoed a proposed merger, despite explicit arguments that the transaction would lead to the creation of a "European champion". ${ }^{94}$ Commenting upon this decision, Commissioner ALMUNIA explicitly said:

"The price of creating a European champion cannot be to let a de facto monopoly dictate its commercial conditions on thousands of European firms operating with European derivatives. (...) A monopoly would have been more beneficial for the parties' shareholders, but it would have harmed customers." 95

The upshot of the above analysis is that competition-related considerations seem to systematically override industrial policy consideration in merger proceedings. Of course, a refined methodological approach would be to look at the Commission's remedial policy. In particular, one could inquire if remedies - especially divestitures - were applied to favour national and/or European champions, at the expense of foreign firms. There would be many ways to test this hypothesis, for instance, by looking at whether foreign firms were more subject to merger remedies than domestic ones. Again, however, a quick glance at the

\footnotetext{
${ }^{89}$ See Commission Decision of 2 October 1991, Case No. IV/M053 - Aerospatiale-Alenia/de Havilland, OJ, 5 December 1991, L 334/42. In May 1991, an Italian and a French firm active in the aviation industry (Aerospatiale and Alenia) sought to takeover de Havilland, a subsidiary of Boeing. The operation would have led to the creation of a group controlling $64 \%$ of the global market for regional turboprop aircrafts and would have had dramatic anticompetitive effects on competition. Italy and France strongly supported the deal, putting forward the virtues of a European aircraft champion. Yet, the Commission adamantly declared the concentration incompatible with the common market. The Commission decision triggered a wave of protests from the Member States, with national officials requiring the resignation of then-competition Commissioner Leon Brittan. See N. LEVY, "EU Merger Control: From Birth to Adolescence", World Competition, 2003, pp. 205-206.

${ }^{90}$ See Commission Decision of 9 November 1994, IV/M.469 - MSG Media Service, OJ, 31 December 1994, L $364 / 1$

${ }^{91}$ See Commission Decision of 14 March 2000, COMP/M. 1672 - Volvo/ScaniaOJ, 29 May 2001, L 143/74. This decision caused the ire of the Swedish authorities which blamed the EU Commission from preventing small countries' firms from reaching scale to compete on international markets. See H. HORN and J. STENEK, "EU Merger Control and Small Member State Interests" in The Pros and Cons of Merger Control, Swedish Competition Authority, 2002, pp. 83-84.

${ }^{92}$ See Commission decision of 30 January 2002, Case COMP/M.2283 — Schneider/Legrand, C(2002) 360, OJ, 6 April 2004, L101/134.

${ }^{93}$ See Commission decision of 26 January 2011, Case COMP/M.5830 — Olympic/Aeagean Airline, OJ, 3 July 2012, C 195/11.

${ }^{94}$ Allegedly needed to rival London's dominance in financial markets. See B. WATERFIELD, "EU blocks NYSE Euronext merger with Deutsche Borse", The Telegraph, 1 February 2012 (available at: http://www.telegraph.co.uk/finance/newsbysector/banksandfinance/9053892/EU-blocks-NYSE-Euronextmerger-with-Deutsche-Borse.html). The Commission blocked the transaction as this would have resulted in a quasi-monopoly in the market for exchange-traded financial derivatives on European interest rates, stock indices and stocks. The two companies together would have controlled more than $90 \%$ of that global market. The parties have introduced annulment proceedings against the Commission's decision, notably on efficiency grounds.

${ }_{95}$ See Competition Commissioner ALMUNIA, Competition policy and growth, European Parliament: Internal Market and Consumer Protection Committee, 28 February 2012, SPEECH/12/131.
} 
statistics published on the Commission's website reveal no greater exposure of non-EU firms to merger remedies.

An alternative would be to look at whether remedies were applied to weaken foreign competitors and strengthen domestic operators, for instance by ordering transfers of assets from the former to the later. But merger decisions simply order divestitures as a matter of principle, and normally leave their implementation to the parties. The purchaser of the divested assets must be found by the seller. Hence, the Commission cannot pro-actively organize the transfer of assets towards EU firms. Our findings are corroborated by the abundant literature on remedies, which does not suggest any industrial policy bias in the Commission's remedial policy under the EUMR. ${ }^{96}$

Overall, there is thus scant evidence that the "targeted industrial policy" considerations play a role in current merger enforcement.

\subsection{Furthering the EU's Competitiveness Policy under the EUMR?}

A distinct question is whether EU merger control has accommodated "competitiveness policy" considerations. Like in Article 102 TFEU cases, a cursory review of the Commission's caselaw shows that only one item of the abovementioned EU's competitiveness agenda has been clearly prevalent in the Commission's merger practice, i.e. the "energy, transport and communication infrastructure" component. As abundantly documented in competition scholarship, the Commission has used its powers under the EUMR to further market-opening reforms in network industries. ${ }^{97}$ For instance, in the Atlas/Phoenix case, ${ }^{98}$ the Commission has relied on the EUMR to open existing infrastructures to competition, and promote the rolling out of new infrastructures. Similarly, in Telia/Telenor, ${ }^{99}$ the Commission cleared the merger only after Norway and Sweden pledged to unbundle the local loop a year ahead of the agenda set in the sector-specific regulatory framework. Likewise, in the

\footnotetext{
${ }^{96}$ See W. WANG, Remedies in EU Antitrust and Merger Control, World Competition, Vol. 34, No. 4, 2011 , p. 571-596; H. VASCONCELOS, "Efficiency gains and structural remedies in merger control", The Journal of Industrial Economics, Volume 58, Issue 4, December 2010, p. 742; P. PAPANDROPOULOS and A. TAJANA, “The Merger Remedies Study_-In Divestiture We Trust?”, European Competition Law Review, 2006, p. 443.

${ }^{97}$ See C. BERGQVIST, Use and Abuse of Competition Law in Pursuit of the Single Market. Has Competition Law Served as Regulation Subject to a Quasi Industrial Policy Agenda?, mimeo (available at: http://antitrustlair.files.wordpress.com/2012/09/use-and-abuse-of-competition-law-1.pdf)

${ }^{98}$ See Commission Decisions of 17 July 1996, Atlas and Phoenix, OJ, 19 September 1996, L 239/23.

${ }^{99}$ See Commission Decision of 13 October 1999, Case IV/M.1439 - Telia/Telenor, OJ, 9 February 2001, L 40/1.
} 
EnBW/EDP/Cajastur/Hidrocantabrico case, ${ }^{100}$ the Commission cleared the transaction subject to commitments from EDF to increase interconnection capacity between the two countries by $2500 \mathrm{MW} .^{101}$

Besides this item, the other components of the EU industrial policy do not seem particularly prevalent in EU merger enforcement. This, however, does not mean that "competitiveness" issues are wholly absent from merger control. For instance, the expansion of the turnover thresholds in 1997 purported to ease costs on businesses. The preamble of the EUMR brings ample evidence of this:

“(1) (...) whereas multiple notification of the same transaction increases legal uncertainty, effort and cost for companies and may lead to conflicting assessments;

(2) Whereas extending the scope of Community merger control to concentrations with a significant impact in several Member States will ensure that a 'one-stop shop' system applies and will allow, in compliance with the subsidiarity principle, for an appreciation of the competition impact of such concentrations in the Community as a whole; (emphasis added)". ${ }^{102}$

In the same spirit, the Commission recently republished a number of merger decisions with a view to help merging companies understand under which conditions they may close transactions before the Commission's final decision. ${ }^{103}$ Such initiatives go at the heart of the "smart regulation" component of the EU's competitiveness agenda.

Overall, merger enforcement is not akin to industrial policy in disguise, even though there are clear areas of convergence between EUMR practice and the EU competitiveness agenda.

\section{State Aid}

In the area of State aid, things are again different, and also simpler. In particular, the Commission has been clearly lenient in relation to Member States "targeted industrial policy" measures. Leaving aside the exceptional rescue measures taken in favor of the banking and

\footnotetext{
100 See Commission Decision of 19 March 2002, COMP/M.2684 - EnBW/EDP/CAJASTUR/ HIDROCANTÁBRICO. The Commission's theory of harm was that, post-merger the French electricity producer EDF would enjoy joint control over Hidrocantabrico through EnBW, so that it would no longer have incentives to import cheaper electricity from France to Spain.

101 This went beyond a standard competition law remedy, which could have consisted EDF's capacity quota on the Franco-Spanish interconnector to a third operator. See M. PIERGIOVANNI, "EC Merger Control Regulation and the Energy Sector: An Analysis of the European Commission's Decisional Practice on Remedies", Journal of Network Industries, 2003, p. 254.

${ }^{102}$ See Council Regulation (EC) No 1310/97 of 30 June 1997 amending Regulation (EEC) No 4064/89 on the control of concentrations between undertakings, OJ, 9 July 1997 L 180/1, Recitals 1 and 2.

${ }^{103}$ C. NELISSE, "Comment : EC provides insight into conditions for crisis buyout derogation in merger review", M-Lex, 14 August 2012,.
} 
financial industries - with massive public interventions to avoid the collapse of systemic players such as Northern Rock ${ }^{104}$, Royal Bank of Scotland ${ }^{105}, \mathrm{ING}^{106}$, Fortis ${ }^{107}$ - many cases brought before the Commission led to the clearance of vertical aid measures addressed to ailing firms. Amongst those, the rescue aid granted to the multinational energy and transport company Alstom is a well-known illustration. ${ }^{108}$ Aids to the benefit of British Energy, ${ }^{109}$ the German MobilCom, ${ }^{110}$ or the French IT company Bull, ${ }^{111}$ are alternative examples of rescue measures cleared by the Commission. On aggregate, official data for the year 2010 shows that a total of $€ 9.1$ billion was granted in support to ailing firms, with the Commission's blessing. ${ }^{112}$

Besides this, the Commission has approved a total of approximately $€ 51.9$ billion of horizontal aid in the same period. ${ }^{113}$ Out of this sum, regional development, environmental protection and R\&D\&I activities account for roughly two thirds of total aid to industry and

\footnotetext{
${ }^{104}$ See Commission Decision of 28 October 2009 on the State aid C 14/08 (ex NN 1/08) implemented by the United Kingdom for Northern Rock, OJ, 5 May 2010, L 112/38.

${ }^{105}$ See Commission Decision of 14 December 2009, Restructuring of Royal Bank of Scotland and participation in the Asset Protection Scheme, OJ, 7 May 2010, C 119/1.

${ }^{106}$ See Commission Decision of 12 November 2008, ING/Netherlands, OJ, 2009, C 328/7.

${ }^{107}$ See Commission Decision of 12 May 2009, Fortis Bank/Belgium, OJ, 31 July 2009, C 178/2

${ }_{108}$ See Commission Decision of 7 July 2004 on the aid measures implemented by France for Alstom, OJ, 10 June 2005, L 150/24. The aid measure saved the French government from a massive social disaster and put back the firm on the track of success.

${ }^{109}$ See Commission Decision of 22 September 2004 on the State aid which the United Kingdom is planning to implement for British Energy plc, OJ, 6 June 2005, L 142/26.

${ }^{110}$ See Commission Decision of 14 July 2004 on the State aid implemented by Germany for MobilCom AG, OJ, 4 May 2005, L116/55.

${ }^{111}$ See Commission Decision of 1 December 2004 on the State aid which France is planning to implement for Bull, OJ, 24 December 2005, 342/81.

112 Official data exclusively refers to state aid expenditures authorized by the Commission under Article 107 TFUE. See EU Commission, Commission Staff Working Paper, Autumn 2011 Update, \{COM(2011) 848 final $\}$, p. 56 (available at: http://ec.europa.eu/competition/state_aid/studies_reports/2011_autumn_working_paper _en.pdf). "The Scoreboard refers to state aid expenditure authorized under Article 107 TFEU and furthermore includes aid granted to the transport sector which is governed by a specific set of rules that refer to Article 107 TFEU. (...) In their annual reports, Member States provide information on all existing aid measures that fall under the scope of Article 107(1) TFEU and which have been authorised by the Commission or implemented by Member States with respect to aid measures falling under the GBER. Cases which are still being examined are excluded."

${ }^{113}$ See Report from the Commission, State Aid Scoreboard. Report on state aid granted by the EU Member States, Autumn 2011 Update, $\operatorname{COM}(2011) 848$ final. Once again, those figures are the result of official data gathering, which focus solely on legal aid. Yet, Member States regularly provide illegal aid to national firms. One part of it is exposed by Commission's investigations and results in recovery orders - during the 2000-2010 decade $€ 14$ billion were ordered to be recovered - while another part is constituted of "black aid" i.e. those illegal aid measures that are never detected by the Commission. Amongst those, the most likely measures to be kept secret by national authorities would logically be the most distortive measures since their notification to the Commission would automatically trigger prohibition decisions. A significant portion of "vertical" measures would thus remain undetected.
} 
services. In other words, competitiveness aid measures are subject to a very liberal regime in EU competition law.

Overall, claims that the EU State aid policy is an anti-industrial policy are, in our opinion, baseless.

\section{Policy Perspective}

In this last section, we attempt to address the difficult question whether industrial policy considerations should play a role in competition law enforcement. To that end, we first analyse whether the economic literature casts any light on this issue (1). We then seek to elicit the viewpoint of EU policy-makers on this issue (2). On this basis, we subsequently consider areas in competition enforcement where adjustments should be made to assist the EU's competitiveness agenda (3).

\section{Overview of the Economic Literature}

This section briefly sketches the pros and cons ascribed to targeted industrial policies (1.1.) and competitiveness policies in the economic literature (1.2), and provides a short conclusion (1.3.).

\subsection{Pros and Cons of Targeted Industrial Policies}

\subsubsection{Pros}

Many arguments usually advanced in support of targeted industrial policies seem based on the need to keep, and possibly increase, economic activity on domestic territory (be it the territory of Member States and/or of the EU). On closer analysis, however, those arguments are more disparate.

Labour - The most standard justification for targeted industrial policies, and in particular protective ones, is that they can help saving "considerable amount of jobs and activities which would otherwise disappear" towards other territories. ${ }^{114}$ In turn, such policies insulate States from a variety of short term economic losses (in the form of social insurance benefits, (re)training costs, etc.).

\footnotetext{
${ }^{114}$ See European Commission, Specifications to invitation to tender, 2008, COMP/2008/A3/015, p. 1 (available at: http://ec.europa.eu/competition/calls/2008a315_tender_specifications.pdf).
} 
Capital - When they take the form of golden shares, of State shareholdings, etc., targeted industrial policies entitle politicians to keep firms' capital in national hands (and shield them from foreign takeover). This, in turn, entitles States to keep some leverage over the management of those firms. Politicians can indeed more easily induce national managers and shareholders to make choices compliant with national interest, than foreign ones. Ultimately, this could help maintain economic activities on national soil.

Economic Efficiency - A key argument in support of fabricating national and/or European champions is that large-size firms are allegedly efficient. To compete effectively on global markets, firms need to achieve economies of scale, synergies, etc. This, in turn, would justify States' measures that encourage external growth (e.g., mergers amongst domestic operators) or that assist domestic firms' internal growth (e.g., through the financing of certain investments). ${ }^{115}$

Political Independence - Selective industrial policy measures are sometimes justified on the ground that they concern sectors which are "strategic" for the political independence of the State. ${ }^{116}$ Such arguments are often made in relation to the defense and media industries. They imply, again, the adoption of protective measures such as golden shares, State shareholding, exclusive rights, etc. in sectors deemed strategic.

Trade Policy (1) - Some economists believe that the government can accelerate the growth of specific firms/sectors with carrots and sticks (financial or not), and foster the country's comparative advantage in global trade. This view is essentially based on empirical data. To take a few examples, proponents of such policies often cite studies on the growth of the Silicon Valley in the US, the rise of a competitive mobile phone industry in Finland, ${ }^{117}$ Japan's automotive leadership in the past four decades, ${ }^{118}$ South Africa's motor industry, ${ }^{119}$ China's "phenomenal manufacturing prowess", Chile's food and wine exports, etc.

\footnotetext{
115 See OECD, Industrial Policy, Competition Policy and National Champions. Background Note, Global Forum in Competition, 16 February 2009, DAF/COMP/GF(2009)1/REV1, p. 4.

${ }^{116}$ See R. WHISH, Competition Law, Lexis Nexis, Butterworths, 5th ed, 2003, p. 826: “A Member State may wish to oppose a concentration for reasons other than its effect on competition possible examples are concentrations which involve foreign take-over of important strategic industries, such as natural resources or energy, or which could be harmful to the free expression of opinion in the press".

${ }^{117}$ See J. LIN and H.-J. CHANG, "Should Industrial Policy in Developing Countries Conform to Comparative Advantage or Defy it? A Debate Between Justin Lin and Ha-Joon Chang", Development Policy Review, 27 (5), 2009, pp. 483-502.

118 Ibid.
} 
Trade Policy (2) - Finally, targeted industrial policy measures offer useful retaliation weapons against protectionist strategies of external trade-partners. ${ }^{120}$ In this sense, such measures can help restore a level playing field in international trade, and protect domestic players from unfair competition strategies and other dumping policies that fall short of WTO law.

Entry - The so-called "infant industry" theory brings support to targeted industrial policy measures, in the form of government-sponsored mergers or subsidies to domestic players. The theory - which remains controversial amongst economists $-{ }^{121}$ goes as follows: where foreign players enjoy first-mover cost advantages (e.g., economies of scale, know-how, etc.), domestic new entrants may be secluded from the market. Public intervention may thus be warranted to help domestic newcomers overcome entry barriers, and in turn stimulate market competition (e.g., through a favourable stance towards merger transactions which entitle small domestic parties to build scale). ${ }^{122}$

\subsubsection{Cons}

Informational Issues - In modern economic theory, the main problem ascribed to targeted industrial policies lies in informational asymmetries. Markets often fail to deliver optimal outcomes because firms have imperfect information. This is a fortiori true of government officials, who are further away from the market than profit-making organisations. ${ }^{123}$ Government officials are indeed bound to rely on second-hand information, of lesser quality,

119 See J. BARNES, R. KAPLINSKY and M. MORRIS, "Industrial Policy in Developing Economies: Developing Dynamic Comparative Advantage in the South African Automobile Sector", Competition \& Change, 8-2, 2004, p. 153.

${ }^{120}$ In a EU context, this protectionist reflex was commented as follows "Too many Member States are reluctant to lift existing barriers, and some are even giving companies yet more power to thwart bids. The protectionist attitude of a few seems to have had a knock-on effect on others. If this trend continues, then there is a real risk that companies launching a takeover bid will face more barriers, not fewer". See European Commission, Press Release, 27 February 2007, IP/07/251.

${ }^{121}$ See H. PACK and K. SAGGI, "The Case for Industrial Policy: A critical Survey”, World Bank Research Paper 3839, February 2009, pp. 4 and ff.; (available at: https://openknowledge.worldbank.org/bitstream/handle/10986/8782/wps3839.pdf); $\quad$ E. $\quad$ MAINCENT and L. NAVARRO, op. cit., pp. 11 and ff.

${ }^{122}$ See D. GERADIN and I. GIRGENSON, "Industrial Policy and European Merger Control - A Reassessment", op. cit., p. 26.

${ }^{123}$ Additionally, the adequacy of specific government interventions in the economy still diminishes with time. Innovation, once driven by "public technology push" for the setting of mega infrastructures (e.g.: railway and telephony networks) is now mainly subject to mechanisms of "market demand pull" whose dynamics are hardly predictable. See J.-L. GAFFARD, "Les relations entre science et industrie : à la recherche d'un modèle économique efficace", Document de travail OFCE, $\mathrm{N}^{\circ}$ 2009-30, November 2009, p. 11 (available at: http://www.ofce.sciences-po.fr/pdf/dtravail/WP2009-30.pdf). Technical complexity along with the acceleration of obsolescence rates contribute to increase the inappropriateness of targeted public mingling measures. 
exhaustivity and neutrality. Hence, faced with complex investment decisions - for instance, assessing the chances of success/recovery of a firm - government officials are in an even worse informational setting than market players. ${ }^{124}$

Capture - Economists also warn against risks of political "capture". Lobbyists may take advantage of the poor informational situation of government officials to convince them of the adequacy of a public intervention in their own private interest.

Public Choice - Government officials do not necessarily act in the public interest. ${ }^{125}$ Elected and appointed officials often pursue their own self agenda, which is dictated by short-term reelection/reappointment constraints. ${ }^{126}$ Government officials thus do not make optimal investment decisions, because they are biased towards those interest groups whose support is decisive for their re-election/reappointment. ${ }^{127}$

Fiscal Issues - Some economists claim - somewhat simplistically in our view - that discretionary industrial policies lead to overspending. ${ }^{128}$ This would strain State budgets in the short term, and would require tax increases in the mid-term. Overall, such measures would be deemed to smoke out growth in the long-term.

Incentives - Public discretionary interventions distort firms' incentives to invest. Public decisions supporting a specific firm generate negative externalities for competitors whose superior efficiency is simply disregarded and neutralized. Firms contemplating green field investments may thus disregard countries with a track record of targeted industrial policy

\footnotetext{
${ }^{124}$ The said informational deficit is, however, not always verified. For instance, it is argued that most State may efficiently build pockets of bureaucratic competence. See D. RODRIK, "Industrial Policy for the Twenty-First Century", op. cit., p. 23. Moreover, the said asymmetries of information may not exist where the State benefits from first-hand intelligence, as it is the case when it has direct control over a major player. Under such specific circumstances, the State is not in a worse situation than market operators. Hence, as an OECD report recently put it, the above-mentioned pitfalls are "not to say that policies aiming to create national champions are never justified. But these results suggest that such policies should be the exception rather than the norm and that the burden of proof should rest squarely upon the governments proposing them rather than upon the sceptics". See OECD, Industrial Policy, Competition Policy and National Champions, op. cit., p. 5.

125 See J. BUCHANAN and G. TULLOCK, The Calculus of Consent: Logical foundations of constitutional democracy, University of Michigan Press 1962, 384 p.

${ }^{126}$ See J. BUCHANAN, The Limits of Liberty: Between Anarchy and Leviathan, Chicago, University of Chicago Press, 1975, 217 p.

${ }^{127}$ See W. NORDHAUS, “The Political Business Cycle”, Review of Economic Studies, 42, 1975, p. 169 and ff. Given the above, government interventions are likely to worsen market outcomes, and exacerbate third parties' distrust in public policy.

${ }^{128}$ See M. DEWATRIPONT and P. SEABRIGHT, “"Wasteful” Public Spending and State Aid Control”, Journal of the European Economic Association, Volume 4, Issue 2-3, April-May 2006, p. 513.
} 
measures, and divert investments towards other locations, where there is less uncertainty as to their ability to thrive if they made the right investment decisions. ${ }^{129}$

\subsection{Pros and cons of "competitiveness" policies}

\subsubsection{Pros}

As seen previously, "competitiveness" policies are assortments of varied policies. They cover education, energy, trade, innovation, competition, labour, tax policies and a myriad of others measures (business-friendly regulation, etc.). And the exact balance between those policies varies across countries.

Economic scholarship thus generally does not study competitiveness policies as such. The literature rather focuses on specific countries or on specific items of the competitiveness policy mix (for instance, education policy).

Short of straightforward theoretical evidence on the merits of competitiveness policies, most arguments remain indirect in nature. A first argument is that competitiveness policies should thus be deemed to enhance welfare, because its various policy items yield, by themselves, proven positive economic effects. ${ }^{130}$ In turn, the evidence in favour of competitiveness policy should thus be traced back to theoretical economic papers on the welfare enhancing effects of labour market flexibility, ${ }^{131}$ education policy, ${ }^{132}$ innovation and technical change, ${ }^{133}$ and other "structural reforms". Similarly, arguments in favour of competitiveness programmes can also be drawn from country-specific empirical studies. For instance, there are dozens of studies on

129 See R. PINDYCK, "Irreversibility, Uncertainty, and Investment", Journal of Economic Literature, Vol. XXIX, p. 1110 (available at: http://www.nber.org/papers/w3307). See also R. CABALLERO, R. PINDYCK, “'Uncertainty, Investment, and Industry Evolution”, International Economic Review, August 1996, vol. 37, $\mathrm{N}^{\circ}$ 3, p. 641. For an illustration case of this phenomenon, see S.FUSS, J. SZOLGAYOVA, M. OBERSTEINER, M. GUSTI, "Investment under market and climate policy uncertainty", Applied Energy, Volume 85, Issue 8, August 2008, p. 708.

${ }^{130}$ OECD economist P. KOWALSKI wrote that: "policies that do not target any particular sectors but rather reflect broad public choices or seek to enhance general resource endowment" are "a potential source of comparative advantage and thus of welfare gains from trade". See P. KOWALSKI, "Comparative Advantage \&nd Trade Performance: Policy Implications"OECD Trade Policy Working Paper No. 121, p.11 (available at: http://search.oecd.org/officialdocuments/displaydocumentpdf/?cote=TAD/TC/WP(2010)38/FINAL\&docLangua $\mathrm{ge}=\mathrm{En})$.

${ }^{131}$ See G. SAINT-PAUL, "Is labour rigidity harming Europe's competitiveness? The effect of job protection on the pattern of trade and welfare", European Economic Review, Volume 41, Issues 3-5, April 1997, p. 499.

132 See R. LUCAS, "On the Mechanics of Economic Development", Journal of Monetary Economics, 22: 3, 1988 , p. 22

133 See R. SOLOW, "Technical Change and the Aggregate Production Function," Review of Economics and Statistics, Vol. 39, 1957, pp. 312-20. 
the positive economic results of the HARTZ labour market reforms introduced in Germany in 2002. ${ }^{134}$

A second indirect argument is that competitiveness policies exhibit none of the shortcomings of targeted industrial policies. In particular, competitiveness policies are neutral and predictable. They are thus more favorable to risk-averse investors, who hate discrimination and unpredictability. Moreover, their neutrality shields government from socially wasteful rent-seeking activities, which distract firms from their core business.

Finally, proponents of competitiveness policies often like to point finger at empirical evidence of massive targeted industrial policy failures. Japan's technological decline since the 1990s or Nokia's ongoing demise in Finland are good examples of this.

\subsubsection{Cons}

Whilst less obvious, the flaws of competitiveness policies are nearly similar to those of targeted industrial policies. First, competitiveness policies also entail making winners and losers. Innovation-friendly policies bring a glaring illustration of this. Such policies can take many shapes. In some cases, governments will decide to strengthen IP protection (e.g. duration, scope, etc.), hence improving the situation of IP holders at the expense of competitors, licensees, users, etc. In other cases, governments will consider that a strong IP system reins in innovation, and will take steps to limit IP protection (e.g., through compulsory licensing orders, price regulation, etc.). In both cases - and regardless of what we believe constitutes the adequate innovation policy - such policy choices favour some interests and harm others. Think, for instance, to the conflicting interests of originating and generic companies in the pharmaceutical sector, or of the divide between software providers and the open-source community, etc.

Second, and in connection with the previous argument, competitiveness policies give rise to intense rent-seeking activities. Because they make losers and winners across the entire economy, the stakes surrounding competitiveness policy choices are even higher than with

\footnotetext{
${ }^{134}$ See S. SCHNEIDER and B. GRAEF, "Germany's jobs miracle: Short-time work, flexible labour contracts and healthy companies", Deutsche Bank Research Briefing, 27 April 2010; H.-P. KLÖS, and H. SCHÄFER, "Krisenmanagement über Variationen des Arbeitsvolumens?", Arbeit, 2-3, 2010, p. 132; J. MÖLLER, "The German labour market response in the world recession - de-mystifying a miracle", Zeitschrift für Arbeitsmarkforschung, 42(4), 2010, p. 325; German Council of Economic Advisors, Jahresgutachten 2009/10: Die Zukunft nicht aufs Spiel setzen, Paderborn, Bonifatius, 2010.
} 
targeted industrial policy choices. For instance, a heteroclite combination boasting opensource software developers, independent music labels, Médecins sans Frontière, the Hacktivist Anonymous group and others lobbied against the Anti-Counterfeiting Trade Agreement, which had been presented by the European Commission as a key competitiveness measure. ${ }^{135}$ The European Parliament eventually rejected the agreement.

Third, on empirical grounds, the contrast between the anaemic state of Western economies on the one hand and the impressive growth of economies such as China, South-Korea and India on the other hand casts doubts on the alleged superiority of competitiveness policies over targeted industrial policy. ${ }^{136}$

Fourth, because they are horizontal in nature, competitiveness policies may lead to a "sprinkling" of resources on a large number of actors and areas, without significant effects. ${ }^{137}$ In recent times, a consensus has manifestly emerged that competitiveness policies should also incorporate some vertical elements including a focus on highly promising sectors. ${ }^{138}$

Finally, conflicts amongst the various components of competitiveness policies may arise. For instance, inconsistencies between innovation policies - in particular, those that support strong patent rights - and competition policy are abundantly documented. In such cases, it is unclear which item should supersede the other.

\subsection{Conclusion}

Economic theory does not bring a firm answer on the merits of industrial policy. Like in other areas of economic theory, scholars are divided, possibly because of ideological biases. This, in itself, should not lead to discard the relevance of industrial policy as a whole. Rather, this suggests that this issue is primarily a matter of policy.

\section{The Policy Perspective}

\footnotetext{
135 See EU Commission, Trade Topics. Intellectual Property (available at: http://ec.europa.eu/trade/creatingopportunities/trade-topics/intellectual-property/).

${ }^{136}$ On State capitalism, see I. BREMMER, State Capitalism Comes of Age. The End of the Free Market?, Foreign Affairs, May/June 2009, 11 p. (http://www.foreignaffairs.com/articles/64948/ian-bremmer/statecapitalism-comes-of-age); IAN BREMMERA. SZAMOSSZEGI and C. KYLE, An Analysis of State-owned Enterprises and State Capitalism in China, U.S.-China Economic and Security Review Commission, October 2011, 122 p. (available at: http://www.uscc.gov/researchpapers/2011/10_26_11_CapitalTradeSOEStudy.pdf).

137 See P. BIANCHI \& S. LABORY, «Empirical Evidence on Industrial Policy using State Aid Data », International Review of Applied Economics, Vol. 20, No. 5, 603-621, December 2006, p.608.

${ }^{138}$ See M. MONTI, A New Strategy for the Single Market at the Service of Europe's Economy and Society, op. cit., p. 88.
} 
As just explained, the question whether industrial policy considerations should play a larger role in competition enforcement is a policy issue, the answer to which largely hinges on personal beliefs. And it is not our intention to provide our personal opinion on this issue. Rather, we want to elicit the EU institutions' mindset on this issue, through theological interpretation. In this respect, several official documents, pronouncements, etc. suggest that the EU institutions consider that the "competitiveness" declination of industrial policy should inform competition enforcement.

Heads of State - To start, the Heads of State have, with the adoption of the Lisbon Treaty, clearly sought to ramp up industrial policy. Surely, the Lisbon Treaty replicates former Article 157 TEC, which, as seen above, does not introduce a legal basis to tinker with competition rules on industrial policy grounds. However, a spirit of change blows on the Lisbon Treaty. First, Article 173(2) TFEU gives the Commission more scope to coordinate the EU and Member States industrial initiatives. ${ }^{139}$ Second, the Lisbon Treaty includes the issue of Foreign Direct Investments within the EU's exclusive competence under the common commercial policy, ${ }^{140}$ thus making such issues subject to the same type of competence as competition policy (Article 3 (b)). Finally, when talking of industrial policy in the Treaty, the Head of State have seemingly endorsed its "competitiveness" variant. Article 173(1) very clearly states that: "The Union and the Member States shall ensure that the conditions necessary for the competitiveness of the Union's industry exist".

European Parliament - In a Draft resolution of 2011, the European Parliament Committee on Industry, Research and Energy, has explicitly taken the view "that competition policy must respond to the needs of an ambitious industrial policy, while respecting the rules of the internal market". ${ }^{141}$ Of course, the legal value of such a draft resolution is, to say the least, weak. Moreover, the Draft resolution remains cryptic on the particular type of industrial policy that it supports. For instance, it seems to support "targeted industrial policy measures" when it pleads for the promotion of 'the emergence of major 'European champions' who set

\footnotetext{
139 See European Commission, European Competitiveness Report 2011, Commission staff working document SEC(2011) 1188, p. 208 (available at: http://ec.europa.eu/enterprise/newsroom/cf/_getdocument.cfm?doc $\frac{\mathrm{id}=7129}{140}$ Article $3 \mathrm{e}$ of the Treaty on the Functioning of the European Union.

141 European Parliament, Motion for a European Parliament Resolution on an Industrial Policy for the Globalised Era, 2010/2095(INI), 3 February 2011, para. 108 (available at: http://www.europarl.europa.eu/sides/getDoc.do?pubRef=-//EP//TEXT+REPORT+A7-2011-

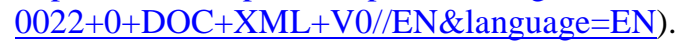


global benchmarks in their sectors of activity". ${ }^{142}$ Yet, it alludes on many occasions to "competitiveness", and supports a twin-track approach, with both a horizontal and sectorspecific focus. ${ }^{143}$

European Commission - Turning, finally, to the European Commission, there is an explicit commitment to anchor competition enforcement in a larger policy agenda. First, the Commission has published five communications on industrial policy since 2002. But even more strikingly, in its Annual Report on Competition Policy for 2011, it declared:

"Competition enforcement and advocacy also serve other wider longer-term objectives such as enhancing consumer welfare, supporting the EU's growth, jobs and competitiveness in line with the Europe 2020 Strategy for smart, sustainable and inclusive growth". ${ }^{144}$

In general, lawyers would typically disavow such declarations as "hot air", i.e. high level declarations of intent, devoid of practical value. Things may, however, be a little different here. In 2011, the Commission issued a report which clearly calls a more operational approach of the relationship between competitiveness considerations and competition enforcement. In the European Competitiveness Report of 2011 ("the Competitiveness Report"), a full Chapter is devoted to "EU industrial policy and Global Competition". And, very interestingly, this Report notes that:

"the EU [must] develop a stronger horizontal coordination of its various instruments and policies. A more in-depth articulation of competition, trade and industrial policies has to be developed, in order to ensure a coherent and consistent approach to the protection of industrial value chains".

With this, the support of officials to the view that there should be the nexus between competition policy and competitiveness has rarely been that clear.

Of course, the Competitiveness Report argues that, on the facts, competitiveness considerations already inform daily competition enforcement. Yet, it also goes on to cautiously innuendo that some domains of competition enforcement may deserve adjustments.

\section{Prospective Perspective}

\footnotetext{
142 Ibid., para. 76.

${ }^{143}$ Ibid., para. 128.

${ }^{144}$ See Communication from the Commission to the European Parliament, the Council, the European economic and social Committee and the Committee of the Regions, Report on Competition Policy 2011, \{SWD(2012) 141 final\}, 30 May 2012.
} 


\subsection{Purpose of this Section}

Now that we now the EU's policy makers desire to twin competitiveness and competition policies, we seek to identify, in this last section, areas of EU competition enforcement where adjustments would be deserved to assist the EU's industrial policy agenda (3.1.1). We then review areas of competition law where interpretative arguments may also be warranted (3.1.2).

\subsubsection{Possible Adjustments to Enforcement Activities}

The Commission's Communication on Industrial Policy sets a comprehensive competitiveness policy programme to be undertaken at EU level. However, as explained previously, in many of those areas, competition enforcement is of little, or no use (e.g., "smart regulation", "access to finance", "counterfeiting and piracy", "stimulate resource efficient investment throughout industry", etc.). In contrast, the Competitiveness Report does a good job at identifying a shortlist of industrial policy "strategic interests" with relevance from a competition standpoint.

Of course one could question why we perform such an analysis, given that the Competitiveness Report itself identifies areas for adjustments. However, the Competitiveness Report understandably remains very deferent, one could say nimble or even commending, to the current enforcement policy pursued by DG COMP ${ }^{145}$ and where it provides suggestions for reform, most of them remain of a fairly high-level nature (e.g., speeding up investigation procedures, limiting the cost of multi filing, etc.). ${ }^{146}$ In this section, we thus purport to push those findings further, and provide more concrete policy suggestions.

\section{a). Access to Resources}

\footnotetext{
145 See Communication from the Commission to the European Parliament, EU Report on Competition Policy 2011, op. cit., p.219: "merger control and antitrust action the toolbox is in place - in merger control for example the failing firm defence, the counterfactual defence, or the efficiency defence can be cited, while antitrust action has the specialisation Block Exemption Regulations and the guidelines on horizontal cooperation agreements. Recent merger cases have included very elaborate restructuring analysis and have clearly demonstrated that a return to profits via the creation of a monopoly goes beyond reasonableness (e.g. Olympic/Aegean). Companies that need to exchange information on past and present strategic data (for example demand or capacities) that can be crucial for the allocation of production to high-demand markets may benefit from the more detailed guidance given in the revised Horizontal Guidelines".

${ }^{146}$ Ibid., p. 219: "An effective regulatory regime, maintaining the competitiveness of European industry, by its very nature requires resources from companies involved in proceedings. The Commission's efforts to reduce the length of investigations (e.g. through the recent introduction of settlement procedures) and increase the transparency and predictability of enforcement can contribute to keeping Europe attractive as a place to invest".
} 
The first strategic interest consists in "access to resources". The Competitiveness Report's concern is that European players may not secure reliable access to essential inputs concentrated in non-EU countries, and in particular to critical raw materials (i.e., antimony, beryllium, cobalt, fluorspar, gallium, germanium, graphite, indium, magnesium, niobium, platinum group metals, rare earths, tantalum and tungsten). In this particular context, the Report suggests to scrutinize long term supply contracts. ${ }^{147}$

This is certainly a commendable suggestion. If we push it further, then, critical raw materials should become an enforcement priority under Article 102 TFEU (which it is not). The refusal to supply doctrine in its two variants (upfront or constructive) could, in particular, be used to secure competitive purchases of critical raw materials by European buyers. Moreover, the Commission could make use of currently unused doctrines, such as the collective dominance theory, in markets where such inputs are controlled by entrenched oligopolists. As the report notes, indeed, those inputs are often "produced by a handful of relatively small suppliers, in some instances only one or two". 148

A more intense scrutiny may also be warranted under the EUMR. ${ }^{149}$ On this particular issue, the Competitiveness Report is a little contradictory. On the one hand, it states that the:

"strategic importance for the integrity of the European industrial fabric increasingly turns
these companies into targets for acquisitions. From an industrial policy perspective, it is
important to closely monitor and assess the consequences, the more so when public authorities
in non-EU countries are involved in such transactions. For example, recent scientific research
suggests that mergers and acquisitions by Chinese companies, which often are state-owned,
are increasingly strategic, building upon the underlying principle of 'digesting rather than
investing'". At the same time, however, the Competitiveness Report praises the EU merger control regime because it applies with equal and neutral vigor to EU and non-EU companies. ${ }^{150}$

In our opinion, the Report falls short of devising any policy prescription in relation to merger. In our view, a possible approach would be to subject to heightened scrutiny all those vertical mergers that involve the acquisition (i) by non EU raw material suppliers, of downstream EU

\footnotetext{
${ }^{147}$ Recalling in parallel their principle pro-competitive nature.

${ }^{148}$ Ibid., p. 220.

${ }^{149}$ Ibid., p.220: "such strategic importance for the integrity of the European industrial fabric increasingly turns these companies into targets for acquisitions".

150 Ibid., p.220: "This neutrality ensures that the merger review process is transparent, manageable and predictable to the investing community. It is also in line with the EU's long-established commitment to openness to the rest of the world, and gives the EU a moral high ground in arguing for non-discriminatory treatment at international level regarding the outgoing investments of European companies in third countries".
} 
capabilities; or (ii) by non EU-players, of upstream EU raw material producers could be subject to heightened scrutiny. ${ }^{151}$

Finally, from a practical standpoint, DG COMP would be well-advised to draw a list of the main non-EU suppliers of raw materials, and engage, as proposed into the report, into a " $f a c t$ finding" exercise, using its investigative powers to request information on their supply contracts with EU customers. The recent investigation into Gazprom's practices is, to some extent, a first step in this direction.

\section{b). Innovation}

The second strategic interest identified in the Report is entitled a "pro-active industrial innovation policy". The Report's chief concern under this section is that "research and innovation capacities in EU firms are numerous and of a high quality, but often small in size and fragmented along national and regional lines". ${ }^{152}$ Measures should accordingly be taken to build large innovation capabilities on EU territory.

Having said that, however, the Report advances no practical proposition in relation to competition enforcement. A possible explanation is that under current EUMR law, mergers or coordination between innovating companies are already subject to favourable assessment standards (e.g., R\&D joint ventures, transfer of technology agreements, etc.).

In this vein, we believe that on two particular aspects, the EU competition rules could undergo some adjustments. First, since the Report insists on the having large innovation capacities in the EU, one could argue that mergers (or cooperation agreements) between EU-owned firms should be treated more leniently than equivalent mergers (or cooperation agreements) involving non EU-owned firms in EU competition law. Whilst we know that this suggestion will certainly be viewed as heretical by both economists and lawyers, ${ }^{153}$ recent economic scholarship indicates that firms' ownership nationality affects the location of their R\&D

\footnotetext{
${ }^{151}$ Ibid., p.220: "the more so when public authorities in non-EU countries are involved in such transactions".

${ }^{152}$ The Report thus seems to endorse the Schumpeterian view that firm size is a key driver for innovation.

${ }^{153}$ Ownership nationality is traditionally disregarded in modern economic thinking. Because global competition incentivizes firms to go multinational and select production sites according to local comparative advantages, shareholders' nationality is said to have no impact on overall efficiency or on job location. For instance, the French car-maker Renault has factory units in no less than twenty-eight countriesdespite its typical status of national champion. See Commissioner for Economic and Monetary Affairs J. ALMUNIA, Le Marché et la Patrie, Science-Po, Paris, 28 March 2006, SPEECH/06/207.
} 
investments. In a remarkable empirical study, ${ }^{154}$ former Chief Economist D. NEVEN finds that multinational firms tend to undertake a disproportionate amount of $R \& D$ investments in their home base. ${ }^{155}$ In other words, home biases exist regarding R\&D investments. ${ }^{156}$ This finding, if confirmed in subsequent research (and if possible, extrapolated to other types of investments such as investments into production facilities, etc.), could form the basis for a differentiated legal treatment of mergers (and cooperation agreements) on the basis of firms' nationality. ${ }^{157}$ To be more accurate, the idea is as follows. Mergers (and cooperation agreements) between EU-owned firms will generate more R\&D investments on EU territory than mergers (and cooperation agreements) between non EU-owned firms. The former are thus more contributive to the EU competitiveness than the later. This, in turn, implies that the efficiency defenses in the EUMR and under Article 101(3) TFEU should kick in more easily (or be subject to a lower burden of proof) in relation to EU-owned firms' transactions in contrast to other transactions, where those efficiencies will primarily benefit to external territories (and consumers). More precisely, it could be considered that the efficiencies will more directly benefit to EU consumers, because those R\&D investments will firstly spill over into macro (e.g., employment) and micro (e.g., product improvement) economic benefits in the territory of the EU. A related, yet still untested argument, is that where firms invest into R\&D on the EU territory, this is likely to be followed by product launch in the EU before product launch in third countries.

154 See D. NEVEN, Ownership, Performance and National Champions, 2008, p. 8 (available at: http://ec.europa.eu/dgs/competition/economist/opnc.pdf).

${ }^{155}$ This is also illustrated by anecdotal evidences such as punctual declarations of business decision makers: "C'est parce que Danone est française que Vitapôle est à Evry, sinon ce centre de recherche et de développement technologique serait à Palo Alto, à Shanghai ou ailleurs". See Institut Montaigne, "Entre stratégie industrielle et politique de concurrence, quelle voie pour l'Europe?", Amicus Curiae - Briefing paper, February 2008, p.3.

${ }^{156}$ More generally, countries where indigenous firms control highly export-focused and technology-based engineering sectors are less impacted by the economic crisis than countries where high-technology sectors are controlled by foreign firms. See B. ANDREOSSO-O'CALLAGHAN and H. LENIHAN, "Responding to the crisis: are policies aimed at a strong indigenous industrial base a necessary condition for sustainable economic growth?", Policy Studies, Volume 32, Issue 4, 2011, p. 325.

157 See Chief Economist D. NEVEN concludes however that restrictions to foreign takeovers should be avoided because it would trigger similar retaliatory measures. On his opinion, foreign external growth opportunities would be more valuable than the benefits resulting from protection against foreign takeovers. Yet, EU firms already face protectionism policies from countries that are amongst EU closest trade partners. For instance, US Foreign Investment and National Security Act of 2007 (FINSA) establishes a framework for the review of foreign acquisitions of US assets by the Committee on Foreign Investment in the United States (CFIUS); likewise, Chinese merger control rules are said to be implemented against foreign firms. See A. HEINEMANN, "Government Control of Cross-Border M\&A: Legitimate Regulation or Protectionism?", Journal of International Economic Law, 2012, 15, pp. 2-5; F. NICOLAS, "Doors Wide Shut? An Update on FDI Regulations in China", Asie Visions, 48, January 2012, p. 2 (available at: http://www.ifri.org/?page=detail-contribution\&id=6992). 
A second area deserving possible adjustments is State aid. ${ }^{158}$ Current State aid rules for research, development and innovation are based on the following logic: the closer the research project is from market, the smaller the aid should be. In turn, the legislation defines three categories of aids, namely aid for fundamental research, aid for industrial research and aid for experimental development that may be exempted according to decreasing levels of aid. ${ }^{159} \mathrm{EU}$ law thus clearly favors fundamental research over industrial and experimental research.

In our opinion, this exemption regime fails to address the so-called "Valley of Death" issue. This concept refers to the widening gap between investments in fundamental research and its subsequent conversion into marketable products and services. ${ }^{160}$ According to economists, many cutting-edge discoveries do not reach industrial stage, but die in the process because they lack support into the "proof of relevancy" phase. ${ }^{161}$ Moreover, the preference given to fundamental research under EU law may contribute to an over-emphasis on upstream research projects, and to lesser investments into applied research, which is often where competitive advantages can be developed. ${ }^{162}$

\footnotetext{
${ }^{158}$ The development of high-tech sectors is traditionally crippled with the defiance of private investors: because innovative firms often exhibit low levels of asset tangibility no collaterals are available to post, what in turn makes access to credit more difficult. See R. RAJAN and L. ZINGALES, "Financial dependence and growth", American Economic Review, 1998, Vol. 88(3), pp. 559 and ff.; M. BRAUN, "Financial contractibility and asset hardness", $\quad$ Mimeo, 2002, $\quad 50 \quad$ p. http://www.law.harvard.edu/programs/corp_gov/papers/Matias_Braun_Paper.pdf). Considering the strategic importance of these sectors, the relevance of State intervention to make up for the failures of the private credit sector is widely acknowledged. See Communication from the Commission, "Europe 2020 A strategy for smart, sustainable and inclusive growth", Brussels, 3 March 2010, COM(2010) 2020 final, p. 24.

${ }^{159}$ See Articles 30 and following of the General block exemption Regulation, op. cit.; Community framework for state aid for research and development and innovation, OJ, 30 December 2006, C 323/ 1.

${ }^{160}$ Notably, the "Valley of Death" phenomenon has been addressed by an EU research group: See High-Level Group on Key Enabling Technologies, Final Report, June 2011, 56 p. (available at: http://ec.europa.eu/enterprise/sectors/ict/files/kets/hlg_report_final_en.pdf). It is also addressed by the UK Parliament. See UK Parliament, Science and Technology Committee, Bridging the "valley of death": improving the commercialisation of research (available at: http://www.parliament.uk/business/committees/committees-az/commons-select/science-and-technology-committee/inquiries/parliament-2010/role-of-the-private-sector/).

161 See D. ROTH, “Addressing the Innovation "Valley of Death:” It's the Products, Stupid!", Xconomy, 26 January 10 (available at: http://www.xconomy.com/san-diego/2010/01/26/addressing-the-innovation-valleyof-death-its-the-products-stupid/); E. CLEMENTS, "Crossing the Valley of Death", Symmetry, February 2011 (available at: http://www.symmetrymagazine.org/article/february-2011/crossing-the-valley-of-death): "It all starts with an innovative idea and a small business loan. The company builds a prototype and proves that the technology works. Maybe a seed grant comes along. Then, somewhere between the laboratory bench and the commercial market, the loans expire and the seed money is gone. The business runs out of cash and out of steam and dies a painful death in a landscape littered with the carcasses of companies that came before."

${ }^{162}$ There is a clear danger for EU research capacities to focus solely on upstream research projects while outsourcing production capacities to emerging countries. "Indeed, it is often in the transition from laboratory to factory that critical skills for competitive advantage are developed, and the development of these skills also involves significant knowledge externalities". See P. AGHION, J. BOULANGER and E. COHEN, "Rethinking industrial policy", op. cit., p. 7. Hence, in order to ensure that EU research excellence is maintained, the preservation of industrial capacities is needed and public support should also be allocated to research down the
} 
Adjustments may thus be appropriate in the field of R\&D\&I aid. The Commission could for instance find inspiration in the recommendations of the High-Level Group on Key Enabling Technologies. ${ }^{163}$ This High-Level Group has proposed to increase the thresholds for project notifications in the GBER to $€ 20$ million per undertaking for experimental development and industrial research projects, in line with the current thresholds applicable to aid to fundamental research.

\section{c). Access to Markets}

Under the third strategic interest, the Report considers that "the need to ensure fair access to markets worldwide is a key ingredient for EU policy in a globalised economy, the more so when Europe faces ever more competitive trading partners". This strategic interest seems to call for fewer adjustments to competition enforcement than the others, simply because "market access" is a core concern of another EU policy, i.e. trade policy.

A similar remark applies to the Report's statement that "Deepening the Single Market plays an essential part in building and strengthening European companies' competitiveness and giving them a 'home base' to compete globally". The deepening of the Single Market is primarily ensured through negative/positive integration measures. And if competition policy has a role to play in the process of market integration, the past decades show that the Commission has been up to the challenge, with its muscular enforcement stance against conduct that undermines market integration.

This does not mean, however, that nothing shall be undertaken. For instance, the Report notes that "the crisis has unsurprisingly turned out to be a period of increased protectionism, precisely in the form of hidden or 'low intensity' barriers". In this context, it may be worthwhile for the Commission to investigate whether such barriers have taken the form of a discriminatory enforcement of antitrust law against EU firms on international markets.

Similarly, when the Report stresses that EU firms' "technical know-how (especially in the form of IPR) need to be protected against arbitrary interventions by the government", on may question whether foreign governments have applied disproportionate antitrust remedies to EU

stage of industrial research. See P. DASGUPTA, "The Welfare Economics of Knowledge Production”, Oxford Review of Economic Policy, 1988, 4, 1-12.

${ }^{163}$ See High-Level Group on Key Enabling Technologies, op. cit., p. 36. We add that the Commission could also consider relaxing intensity thresholds regarding these two items. 
firms with a view to appropriate some of their intangible assets. If those hypotheses were confirmed, it could be interesting to subject those issues to discussion within international foras, such as the International Competition Network ("ICN").

\section{d). Restructuring}

The last strategic interest that should permeate competition enforcement is the "transition to more sustainable and innovative production and/or new business models", in other words, the "restructuring" or European industry. According to the Competitiveness Report, restructuring should be a priority in the "the automotive sector, the basic metals industries, mechanical and electrical engineering, shipbuilding or the printing industry".

In those sectors, a more flexible approach under Article 101 TFEU (especially in relation to horizontal cooperation agreements), the EUMR and State aid rules may thus be appropriate.

Besides this, one related area - not mentioned in the Report - where EU competition law may need a fix is State aid, and in particular the rules on aid for rescuing and restructuring firms in difficulty. In EU law, restructuring aids are treated severely. ${ }^{164}$ Such aids are subject to rigorous conditions such as the "one time, last time" principle, or compensatory measures that mitigate distortive effects on competitors.

However, the existing rules pay little attention to the impact of the aid on the beneficiary's environment, in particular, when the latter is an ailing firm dominating a business cluster of smaller innovative firms. ${ }^{165}$ The literature on business clusters shows that small firms often benefit from the presence of the business cluster leader for the industrial development of their researches. ${ }^{166}$ Safeguarding the business cluster leader viability may actually be indispensable to help a network of innovative firms cross the above-mentioned "Valley of Death". In such circumstances, the Commission should thus balance the aid's anticompetitive effects with the

\footnotetext{
${ }^{164}$ The exit of inefficient firms is said to be "a normal part of the operation of the market" while aids for rescue and restructuring operations are said to be "among the most distortive types of State aid." See Communication from the Commission, Community guidelines on State aid for rescuing and restructuring firms in difficulty, OJ, 1 October 2004, 244/2, Recital 4.

165 See O. FALCK and S. HEBLICH, "Do We Need National Champions? If So, Do We Need a ChampionsRelated Industrial Policy? An Evolutionary Perspective”, Jena Economic Research Papers, 2007-088, pp. 15 and 16 (available at: http://zs.thulb.uni-jena.de/receive/jportal_jparticle 00082398).

166 Examples of big manufacturing companies sustaining the activities of a whole cluster are manifold. "In Europe, the Dresden cluster centres around the chip factories of Infineon and AMD, the nanoelectronics cluster in Rhône-Alpes around STMicroelectronics (in addition to Philips and Motorola), the cluster in Eindhoven around a broad array of technological activities by Philips, and a final example is of the well-known case of Nokia and its impact on the Finnish economy." See E. MAINCENT and L. NAVARRO, op. cit., p. 18.
} 
role of the ailing firm within its business environment as it would be inefficient to let a whole cluster go to waste. ${ }^{167}$ Interestingly, the Preamble of the Guidelines on State aid for rescuing and restructuring firms in difficulty may be (re)interpreted as open to such considerations. Recital 8 states that the provision of rescue or restructuring aid may:

"be justified, for instance, by social or regional policy considerations, by the need to take into account the beneficial role played by small and medium-sized enterprises (SMEs) in the economy or, exceptionally, by the desirability of maintaining a competitive market structure when the demise of firms could lead to a monopoly or to a tight oligopolistic situation" (emphasis added). ${ }^{168}$

If more explicit amendments were to be envisioned, the anticipated reform of State aid law could provide an opportunity for adjustments. ${ }^{169}$

\subsubsection{Adjustments to the Law?}

As surmised earlier, the legal principles that govern the interpretation of the EU competition rules may deserve some change. This is particularly the case of the defenses available under Article 101, 102 and the EUMR to justify otherwise anticompetitive practices. If a fair share of efficiencies that result from transactions from/between EU owned firms (mergers, agreements and unilateral conduct) accrues more to EU consumers, than similar efficiencies yielded by transactions from/between non-EU firms, then this should be explicitly reflected in the law, in particular in Guidelines adopted under Article 101, 102 and EUMR. Alternatively, a lower burden of proof of efficiencies may be applied to transactions from/between EU firms, and a higher one shall apply to transactions from/between non-EU firms. For instance, whilst qualitative demonstration of efficiencies may pass the bar for transactions

\footnotetext{
${ }^{167}$ The ability of the firm in difficulty to restructure would still be a necessary condition to any aid measure any other option would leave the door open to endless bailout plans - , but the indispensability of the firm for the good performance of the whole cluster would mitigate considerations on the harm done to competitors. This statement does not mean that any operator tied up with a plurality of stakeholders should see its business position be taken into account, though. Only regional, indispensable bridges over the Valley of Death would benefit from a plus point in the global assessment of the aid measure. For instance, the rescue of national flagship carriers is usually irrelevant for the industrial base: since stakeholders essentially lean upon the activities generated by the regional airport and may as well trade with a competitor air carrier, rescue measures may be dismissed. Conversely, the fall of the French Alstom would have inevitably dragged an otherwise very competitive industrial base into bankruptcy since no other firm could have replaced it as head of the regional cluster. Its insolvency would have resulted in a total of 216,400 direct or indirect job losses. See Commission Decision of 7 July 2004 on the aid measures implemented by France for Alstom, op. cit., para. 85 and 90.

${ }^{168}$ See Communication from the Commission, Community guidelines on State aid for rescuing and restructuring firms in difficulty, op. cit., Recital 8.

${ }^{169}$ See EU Commission, Public consultations, Consultation on the Review of the EU state aid rules for research, development and innovation (available at: http://ec.europa.eu/competition/consultations/2012_stateaid_rdi/index_en.html).
} 
from/between EU firms, a more sophisticated type of evidence (quantitative) may be requested from non EU firms.

\section{Conclusions}

The EU Courts believe that the competition rules shall not apply in a vacuum, disregarding other EU public policies, including industrial policy.

Until recently, the Commission has erred on the side of caution, and has promoted an orthodox approach of competition enforcement which leaves little place to industrial policy considerations, to the exception of infrastructure-related issues in network industries. The sole possible area where industrial policy considerations have been pervasive in modern competition law is State aid.

Things may however change with the publication of the Competitiveness Report. This document identifies possible enforcement targets. The Directorate General for Competition, could find in this report a source of inspiration for pro-actively applying competition law where it actually matters, rather than (i) been dragged into endless revenue sharing disputes amongst hi tech players (in the field of abuse of dominance); and (ii) running a passive cartel policy, by dealing with leniency applications as they come by, through the mailbox. 


\section{Annex I - Table of the Article 102 TFEU Decisions adopted since 1 May 2004 (under both Article 7 and 9 of Regulation 1/2003)}

\begin{tabular}{|c|c|c|c|}
\hline Date & Case & Sector & Firm nationality \\
\hline 02.06 .2004 & $\begin{array}{l}\text { PO/Clearstream (Clearing } \\
\text { and settlement) }\end{array}$ & $\begin{array}{l}\text { Banking and } \\
\text { financial markets }\end{array}$ & EU \\
\hline 22.06 .2005 & Coca-Cola & Consumer goods & US \\
\hline 22.02 .2006 & $\begin{array}{l}\text { ALROSA + DBCAG (part of } \\
\text { de Beers group) + City and } \\
\text { West East (part of de Beers } \\
\text { group) }\end{array}$ & Raw materials & EU \\
\hline 29.03 .2006 & Prokent/Tomra & Consumer goods & Norway \\
\hline 04.07 .2007 & Telefonica S.A. (broadband) & $\begin{array}{l}\text { Network } \\
\text { industries }\end{array}$ & EU \\
\hline 11.10 .2007 & Distrigaz & $\begin{array}{l}\text { Network } \\
\text { industries }\end{array}$ & EU \\
\hline 26.11 .2008 & $\begin{array}{l}\text { German electricity wholesale } \\
\text { market }\end{array}$ & $\begin{array}{l}\text { Network } \\
\text { industries }\end{array}$ & EU \\
\hline 26.11 .2008 & $\begin{array}{l}\text { German electricity balancing } \\
\text { market }\end{array}$ & $\begin{array}{l}\text { Network } \\
\text { industries }\end{array}$ & EU \\
\hline 18.03 .2009 & RWE gas foreclosure & $\begin{array}{l}\text { Network } \\
\text { industries }\end{array}$ & EU \\
\hline 13.05 .2009 & Intel & Hi tech industries & US \\
\hline 03.12 .2009 & GDF foreclosure & $\begin{array}{l}\text { Network } \\
\text { industries }\end{array}$ & EU \\
\hline 09.12 .2009 & Rambus & Hi tech industries & US \\
\hline 16.12 .2009 & Microsoft (Tying) & Hi tech industries & US \\
\hline 17.03 .2010 & $\begin{array}{l}\text { Long term electricity } \\
\text { contracts in France }\end{array}$ & $\begin{array}{l}\text { Network } \\
\text { industries }\end{array}$ & EU \\
\hline 14.04 .2010 & Swedish Interconnectors & $\begin{array}{l}\text { Network } \\
\text { industries }\end{array}$ & EU \\
\hline 04.05 .2010 & E.On gas foreclosure & $\begin{array}{l}\text { Network } \\
\text { industries }\end{array}$ & EU \\
\hline 29.09 .2010 & ENI & $\begin{array}{l}\text { Network } \\
\text { industries }\end{array}$ & EU \\
\hline 22.06 .2011 & Telekomunikacja Polska & $\begin{array}{l}\text { Network } \\
\text { industries }\end{array}$ & EU \\
\hline 15.11 .2011 & Standard and Poor's & $\begin{array}{l}\text { Banking and } \\
\text { financial markets }\end{array}$ & US \\
\hline 13.12 .2011 & IBM - Maintenance services & Hi tech industries & US \\
\hline
\end{tabular}


Paper prepared for the 2012 GCLC Annual Conference - Work in progress 